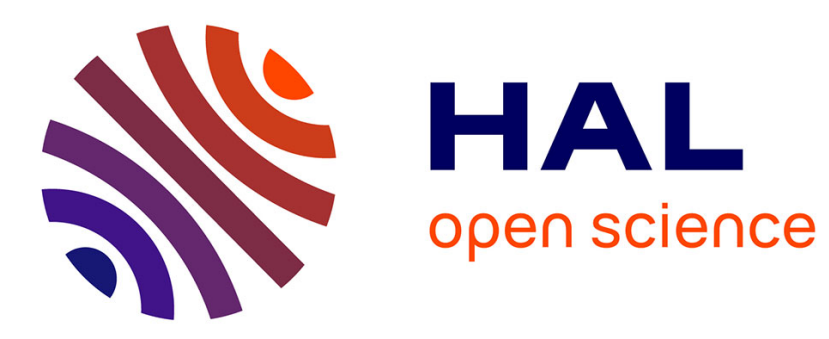

\title{
Polymorphism of K2ZrF6
}

L’ubomír Smrčok, Armel Le Bail, Miroslav Boča, Aydar Rakhmatullin

\section{To cite this version:}

L'ubomír Smrčok, Armel Le Bail, Miroslav Boča, Aydar Rakhmatullin. Polymorphism of K2ZrF6.

Crystal Growth \& Design, 2020, 20 (6), pp.3867 - 3881. 10.1021/acs.cgd.0c00166 . hal-03464331

\section{HAL Id: hal-03464331 \\ https://hal.science/hal-03464331}

Submitted on 3 Dec 2021

HAL is a multi-disciplinary open access archive for the deposit and dissemination of scientific research documents, whether they are published or not. The documents may come from teaching and research institutions in France or abroad, or from public or private research centers.
L'archive ouverte pluridisciplinaire HAL, est destinée au dépôt et à la diffusion de documents scientifiques de niveau recherche, publiés ou non, émanant des établissements d'enseignement et de recherche français ou étrangers, des laboratoires publics ou privés. 


\title{
CRYSTAL GROWTH EDDESIGN
}

Subscriber access provided by BIU Pharmacie | Faculté de Pharmacie, Université Paris V

\section{Article}

\section{Polymorphism of K2ZrF6}

\author{
\#ubomír Smr\#ok, Armel Le Bail, Miroslav Boca, and Aydar Rakhmatullin
}

Cryst. Growth Des., Just Accepted Manuscript • DOI: 10.1021/acs.cgd.0c00166 • Publication Date (Web): 22 Apr 2020

Downloaded from pubs.acs.org on April 27, 2020

\section{Just Accepted}

"Just Accepted" manuscripts have been peer-reviewed and accepted for publication. They are posted online prior to technical editing, formatting for publication and author proofing. The American Chemical Society provides "Just Accepted" as a service to the research community to expedite the dissemination of scientific material as soon as possible after acceptance. "Just Accepted" manuscripts appear in full in PDF format accompanied by an HTML abstract. "Just Accepted" manuscripts have been fully peer reviewed, but should not be considered the official version of record. They are citable by the Digital Object Identifier (DOI®). "Just Accepted" is an optional service offered to authors. Therefore, the "Just Accepted" Web site may not include all articles that will be published in the journal. After a manuscript is technically edited and formatted, it will be removed from the "Just Accepted" Web site and published as an ASAP article. Note that technical editing may introduce minor changes to the manuscript text and/or graphics which could affect content, and all legal disclaimers and ethical guidelines that apply to the journal pertain. ACS cannot be held responsible for errors or consequences arising from the use of information contained in these "Just Accepted" manuscripts. 


\title{
Polymorphism of $\mathrm{K}_{2} \mathrm{ZrF}_{6}$
}

\author{
Lubomír Smrčok $^{1, \dagger}$, Armel Le Bail², Miroslav Boca*,1, Aydar Rakhmatullin ${ }^{3}$
}

${ }^{1}$ Institute of Inorganic Chemistry, Department of molten systems, Dubravska cesta 9, Bratislava; 845 36, Slovakia, miroslav.boca@savba.sk

${ }^{2}$ Institut des Molécules et des Matériaux du Mans, CNRS UMR 6283, Université du Maine, Avenue Olivier Messiaen, 72085 Le Mans Cedex 9, France, Armel.le_Bail@univ-lemans.fr

${ }^{3}$ Conditions Extremes et Materiaux: Haute Temperature et Irradiation, $1 D$ avenue de la Recherche Scientifique CS 90055,45071 Orleans cedex 2,France, aydar.rakhmatullin@cnrsorleans.fr

* corresponding author: Miroslav Boča, miroslav.boca@savba.sk

$\dagger$ in memoriam: Lubomír Smrčok

KEYWORDS: di-potassium zirconium fluoride, polymorphism, synchrotron powder diffraction, ${ }^{19} \mathrm{~F}$ MAS NMR

\begin{abstract}
Heating of the $\mathrm{K}_{2} \mathrm{ZrF}_{6}$ room temperature monoclinic form-I reveals a complex polymorphism investigated by synchrotron powder temperature-dependent diffraction. The first thermal event at $240{ }^{\circ} \mathrm{C}$ corresponds to the quasi-simultaneous apparition of four different phases (noted II to V) of which only three could be indexed and two completely characterized structurally. Form-II (structure unrefined) is very probably hexagonal $(a=6.4473(1) \AA, c=3.8606(1) \AA$ at 264 ${ }^{\circ} \mathrm{C}, Z=1$ ). Form-III is cubic (space group $F m \overline{3} m, a=9.0804(1) \AA$ at $264{ }^{\circ} \mathrm{C}, Z=4$ ), related to $\mathrm{K}_{3} \mathrm{ZrF}_{7}$. Form-IV remains unindexed, presenting broad diffraction peaks. Form-V is present as a weak impurity at this stage, increasing in proportion after the second thermal event at $288^{\circ} \mathrm{C}$ where a new form-VI is built. Form-V is tetragonal (space group $P 4 / n m m, a=6.3281$ (1) $\AA, c=9.3671(2)$ $\AA$ at $295^{\circ} \mathrm{C}, \mathrm{Z}=2$ ) and form-VI is orthorhombic (space group Cmcm, $a=6.40840(5) \AA, b=$ 20.7697(2) $\AA, c=19.9888(2) \AA$, at $295^{\circ} \mathrm{C}, Z=16$ ). At $317^{\circ} \mathrm{C}$, form-VI transforms into form-V. At $449^{\circ} \mathrm{C}$, a different orthorhombic form-VII is disclosed (space group Pnma, $a=10.3084(1) \AA$,
\end{abstract}


$b=6.0291(1) \AA, c=23.8023(2) \AA$, at $495{ }^{\circ} \mathrm{C}, Z=8$ ), coexisting with the cubic form-III. On cooling, form VII of which an approach of the crystal structure is provided, returns to form V at $411^{\circ} \mathrm{C}$ which looks stable down to $139^{\circ} \mathrm{C}$ giving form I back. Isolated $\mathrm{ZrF}_{6}$ octahedra are present in forms-III, -V, -VI, -VII. Form-VI contains also dimeric entities $\mathrm{Zr}_{2} \mathrm{~F}_{12}$ built from a $\mathrm{ZrF}_{7}$ monocapped trigonal prism sharing a corner with a $\mathrm{ZrF}_{6}$ octahedron. Form-VII structure is related to form-V by quadrupling the tetragonal $a$ parameter, the reversible $\mathrm{V} \leftrightarrow \mathrm{VII}$ transition is very probably topotactic. The coexistence of several phases at each temperature above the first transition at $240{ }^{\circ} \mathrm{C}$ was observed. Peak multi-splitting is observed at many temperatures that suggests the occurrence of coexisting micro-phases. The parallel existence of several phases was observed also by ${ }^{19} \mathrm{~F}$ MAS NMR spectroscopy measured from $250{ }^{\circ} \mathrm{C} \rightarrow 410^{\circ} \mathrm{C} \rightarrow \mathrm{RT}$.

\section{INTRODUCTION}

In the concept of so-called "Generation IV" Molten Salts Nuclear Reactors (MSR) fission power should be produced in a circulating molten salt fuel mixture. Currently, these types of reactors are considered to be fuelled with uranium or thorium fluorides dissolved in a mixture of molten fluorides, with $\mathrm{Na} / \mathrm{K}$ and $\mathrm{Zr}$ fluorides being a primary option ${ }^{1}$. The compounds belonging to the $\mathrm{KF}-\mathrm{ZrF}_{4}$ system have several potential uses: i) as solvent media in a reactor core or as solvent for pyrochemical reprocessing of actinides and lanthanides produced in nuclear reactions; ii) as moderators; iii) as cooling media of the reactor core, iv) as high temperature transport media providing transport of heat to hydrogen production facilities employed for the Hydrogen Economy Concept ${ }^{2}$. In all of the above applications the compatibility of the molten salt with reactor construction materials is necessary to avoid chemical attack by a corrosive liquid. Considering the working regime of a MSR it is evident that reliable reference data on the dynamics of phase transitions in zirconium fluorides are essential for design of a cooling unit. However, the only available phase diagram of $\mathrm{KF}_{-} \mathrm{ZrF}_{4}$ system was reported in $1961^{3}$ and although it has brought initial information, some results are seriously limited by the use of low resolution laboratory powder diffraction. None of the high temperature phases was the subject of a crystal structure refinement by the Rietveld method. Among the compounds belonging to the $\mathrm{KF}-\mathrm{ZrF}_{4}$ system it is $\mathrm{K}_{2} \mathrm{ZrF}_{6}$ which seems to be, mainly for the economic reasons, the most promising candidate for future application. For its solid-solid phase transformations the following scheme was suggested 3: 
$\alpha-\mathrm{K}_{2} \mathrm{ZrF} 6 \frac{240^{\circ} \mathrm{C}}{\stackrel{130^{\circ} \mathrm{C}}{\rightleftarrows}} \beta-\mathrm{K}_{2} \mathrm{ZrF}_{6} \stackrel{288^{\circ} \mathrm{C}}{\longleftarrow} \gamma-\mathrm{K}_{2} \mathrm{ZrF} 6 \stackrel{445^{\circ} \mathrm{C}}{\longleftarrow} \delta-\mathrm{K}_{2} \mathrm{ZrF} 6 \stackrel{585^{\circ} \mathrm{C}}{\rightleftarrows}(1)+\mathrm{K}_{3} \mathrm{ZrF} 7$

For the region above $585{ }^{\circ} \mathrm{C}$ a series of phase transformations resulting in the co-existence of solid and liquid phases was suggested, but the region has not yet been explored in details. At room temperature, the crystal structure of $\mathrm{K}_{2} \mathrm{ZrF}_{6}$ is monoclinic, $C 2 / c^{4,5}$. The structure of $\beta-\mathrm{K}_{2} \mathrm{ZrF}_{6}$ is not reliably known in spite of several suggestions ${ }^{6,7}$. Phase transitions in the temperature range of $\sim 240$ to $245{ }^{\circ} \mathrm{C}$ were independently confirmed only by NMR ${ }^{7}$. Recently, some more detailed analysis of phase transformation of $\mathrm{K}_{2} \mathrm{ZrF}_{6}$ was reported in the region up to $330{ }^{\circ} \mathrm{C}{ }^{8,9}$ using XRD, DTA/DSC, Raman spectroscopy and statistical methods PCA and MCR, as well as phase diagram of the system ( $\mathrm{LiF}-\mathrm{NaF}-\mathrm{KF})_{\text {eut }}-\mathrm{K}_{2} \mathrm{ZrF}_{6}{ }^{10}$. Detailed room temperature analysis by XPS and NMR spectroscopy was provided, as well ${ }^{11,12}$.

The very poor knowledge of the $\mathrm{K}_{2} \mathrm{ZrF}_{6}$ thermal behaviour regarding to its potential industrial and economic importance incited us to re-examine the problem by synchrotron temperaturedependent diffraction experiments. Our results led to the observation of seven $\mathrm{K}_{2} \mathrm{ZrF}_{6}$ phases instead of four, requiring to change the above Greek notation by using forms-I to VII. Correspondences with the polymorphism of $\mathrm{K}_{2} \mathrm{HfF}_{6}{ }^{13}$, for which structure models were proposed (but no Rietveld or single crystal structure refinement) for six different phases, are discussed.

\section{EXPERIMENTAL SECTION}

Preparation of $K_{2} Z_{r} F_{6}$ : For the preparation of the title compound the following chemicals were used: $\mathrm{ZrO}_{2}$ (Chiron, $98.5 \%$ ), $\mathrm{KHF}_{2}$ (Lachema, 99\%), KF (Sigma-Aldrich, $99 \%$ ), $\mathrm{ZrF}_{4}$ (prepared at the Institute of Chemistry KSC RAS, Apatite, Russia; min. 99.5\%; no impurities could be detected by powder XRD), $\mathrm{HF}$ (38-40 wt \% in $\mathrm{H}_{2} \mathrm{O}$; Lachema). KF was dried in vacuum at 130 ${ }^{\circ} \mathrm{C}$ for $24 \mathrm{~h}$; other chemicals were used without further purification. The handling of $\mathrm{KF}$ and $\mathrm{ZrF}_{4}$ was done in a glove box under dry argon atmosphere (Messer Tatragas, 99.9990 \%) with moisture content below 10 ppm.

Zirconium oxide $(0.01 \mathrm{~mol}, 1.232 \mathrm{~g})$ was dissolved in hydrofluoric acid $\left(10 \mathrm{wt} \%\right.$ in $\mathrm{H}_{2} \mathrm{O}$; $30 \mathrm{~mL})$ by continuous stirring and heating $\left(80-90^{\circ} \mathrm{C}\right)$ in a platinum dish. Potassium hydrogen fluoride $(0.02 \mathrm{~mol}, 1.562 \mathrm{~g})$ was added and the reaction mixture was stirred for ca. one hour. The resulting clear solution was filtered through a folded paper filter into a plastic beaker and left to crystallise at ambient temperature. After two days, the oblong colourless crystals were removed 
and dried in a desiccator at ambient temperature (1.147 g, $40 \%)$. The studied compound can be prepared by the described procedure using zirconium fluoride $(0.01 \mathrm{~mol}, 1.672 \mathrm{~g})$ instead of zirconium oxide and/or potassium fluoride $(0.02 \mathrm{~mol}, 1.162 \mathrm{~g})$ instead of potassium hydrogen fluoride. It is crucial to use the right concentration of hydrofluoric acid. The use of highly concentrated solution is resulting into formation of solvated product $\mathrm{K}_{2} \mathrm{ZrF}_{6} \cdot \mathrm{HF}{ }^{14}$, while from pure water solution $\mathrm{K}_{3} \mathrm{ZrF}_{7}$ crystallises ${ }^{15}$. Two $\mathrm{K}_{2} \mathrm{ZrF}_{6}$ samples were made, noted samples 1 and 2 below, which were used for mainly two different synchrotron experiments (both fraction might differ in grain size).

DSC-TGA Analysis: Thermogravimetric experiments were carried out on a thermoanalyzer TA instrument DT-Q600 under argon at a heating rate of $5{ }^{\circ} \mathrm{C} \mathrm{min}^{-1}$ from room temperature up to 500 ${ }^{\circ} \mathrm{C}$ and back, allowing to characterize a strong hysteresis (Figure 1). This DSC shows mainly four endothermic effect on heating $\left(240,288,317\right.$ and $\left.445^{\circ} \mathrm{C}\right)$ and two exothermic effects on cooling $\left(411\right.$ and $139^{\circ} \mathrm{C}$ ). If one does not consider the $317^{\circ} \mathrm{C}$ peak, the heating seems to be compatible with the previous model ${ }^{3}$ of $\alpha \rightarrow \beta \rightarrow \gamma \rightarrow \delta$ transitions given in the introduction, but not with any reversibility (also compare with ${ }^{9}$ ).

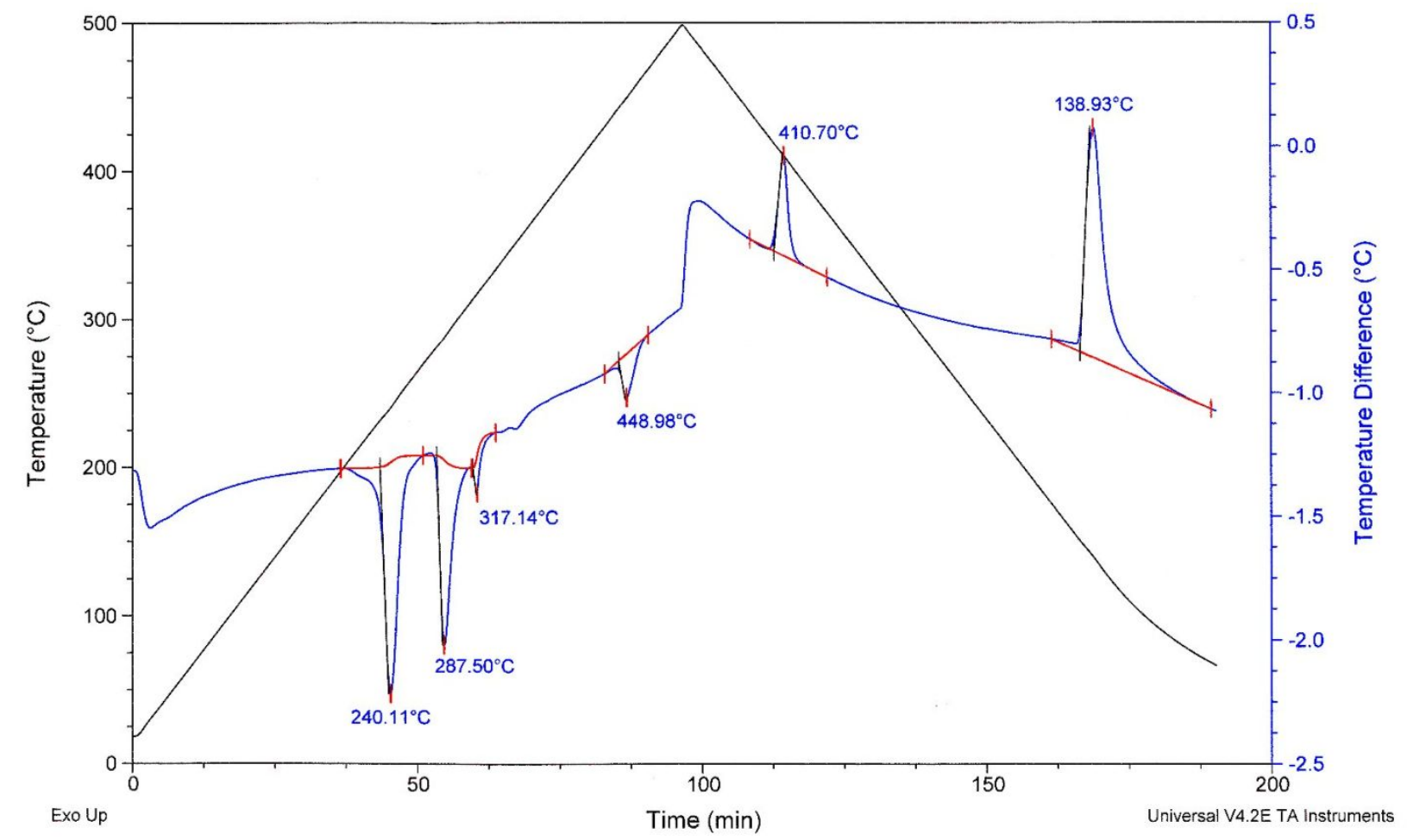

Figure 1. DSC thermal analysis of $\mathrm{K}_{2} \mathrm{ZrF}_{6}$ by DSC under argon at a heating rate of $5{ }^{\circ} \mathrm{C} \mathrm{min}^{-1}$ from room temperature up to $500{ }^{\circ} \mathrm{C}$ and back. 

heated system ${ }^{9}$. In addition, to enhance resolution at room temperature a probe with $1.3 \mathrm{~mm}$ diameter rotors spinning at a frequency of $50 \mathrm{kHz}$ was used. The parameters were: pulse width $0.95 \mu \mathrm{s}(\pi / 2)$, relaxation delay $300 \mathrm{~s}\left(6 \mathrm{~T}_{1}\right)$, and 4 scans. The ${ }^{19} \mathrm{~F}$ chemical shift was referenced to $\mathrm{CFCl}_{3}$. The DMFIT program was applied to simulate the spectra and fit the peaks ${ }^{16}$.

Powder X-ray Diffraction (PXRD): Data were recorded using beamline I11 at the Diamond Light Source, Didcot, UK. Samples were mounted in a sapphire capillary, in dry box under argon atmosphere, that was closed by glue on both sides for measurements in transmission geometry. Two main experiments were made, using the Mythen detector configuration on sample $\mathbf{1}$ and the multianalyzing crystal-detectors (MACs) on sample 2, both operating at wavelength close to 0.827 $\AA$. The beamline set-up and characteristics are described in the literature ${ }^{17-19}$. The diffraction data were collected in order to obtain significant patterns in the temperature range $20-500{ }^{\circ} \mathrm{C}$.

Data interpretations were sometimes facilitated by the previous results about $\mathrm{K}_{2} \mathrm{HfF}_{6}$ in 1983 by Saalfeld and Guse ${ }^{13}$. From their GUINIER-powder diagrams (high-temperature chamber), they indexed a tetragonal phase $\left(190-250{ }^{\circ} \mathrm{C}, a=6.29(8) \AA, c=9.27(4) \AA\right.$ at $210{ }^{\circ} \mathrm{C}$, suggested space group $P 4 / \mathrm{mmm}$ ) and proposed it to be related to distorted variants of the cubic elpasolite ${ }^{20}$. $\mathrm{KNaAlF}_{6}$ having similar cell parameters $\left(a \sim 6.5 \AA, c \sim 9.5 \AA\right.$ for $\left.\left(\mathrm{NH}_{4}\right)_{3} \mathrm{MF}_{6}, \mathrm{M}=\mathrm{In}, \mathrm{Sc}\right)$ described by Bode and Voss ${ }^{21}$. Saalfeld and Guse ${ }^{13}$ identified a cubic $\mathrm{K}_{2} \mathrm{HfF}_{6}$ phase $\left(210-380{ }^{\circ} \mathrm{C}, a=9.01(6)\right.$ $\AA$ at $240{ }^{\circ} \mathrm{C}$, space group $F m \overline{3} m$, proposing a structure related to elpasolite or to $\mathrm{K}_{2} \mathrm{PtCl}_{6}$ ) ${ }^{22}$ and sometimes a hexagonal phase $\left(170-220{ }^{\circ} \mathrm{C}, a=6.40(5), c=3.81(8)\right.$ at $200{ }^{\circ} \mathrm{C}$, no systematic extinction) which they proposed to be similar to $\beta_{1}-\mathrm{K}_{2} \mathrm{UF}_{6}$ and $\beta_{1}-\mathrm{K}_{2} \mathrm{ThF}_{6}$, with the space group $P \overline{6}$ $2 m$, that were investigated by Zachariasen ${ }^{23}$. Saalfeld and Guse ${ }^{13}$ noted that the $\gamma-\mathrm{K}_{2} \mathrm{ZrF}_{6}$ powder pattern from Novoselova et al. ${ }^{3}$ was analogous to that of their hexagonal $\mathrm{K}_{2} \mathrm{HfF}_{6}$ phase, unfortunately they never confirmed their structure models by any Rietveld refinement. These $\mathrm{K}_{2} \mathrm{HfF}_{6}$ hexagonal, cubic and tetragonal three phases were recognized (using search-match identification process by means of the EVA software ${ }^{24}$ combined with the ICDD-PDF-4+ powder patterns database) ${ }^{25}$ to occur simultaneously in the case of $\mathrm{K}_{2} \mathrm{ZrF}_{6}$, with similar cell parameters as those of the Hf-based compounds, they were noted phases II, III and V, respectively. A fourth phase noted IV is also present at this stage, all of these phases corresponding to the " $\beta-\mathrm{K}_{2} \mathrm{ZrF}_{6}$ " in the Novoselova et al. notation. ${ }^{3}$. 
A contour plot of a synchrotron thermo-diffractogram of $\mathrm{K}_{2} \mathrm{ZrF}_{6}$ covering the range $185-300{ }^{\circ} \mathrm{C}$ is shown in Figure 2, with phase numbering. This figure shows that the $288{ }^{\circ} \mathrm{C}$ thermal event corresponds to the complete collapse of the hexagonal phase-II (phase IV having not totally disappeared yet at $295^{\circ} \mathrm{C}$ ), a strong decrease in the proportion of the cubic phase-III, a strong increase in the proportion of the tetragonal phase- $\mathrm{V}$ and the occurrence of a new phase VI for which no similar powder pattern could be found in the $\mathrm{K}_{2} \mathrm{HfF}_{6}$ previous study.

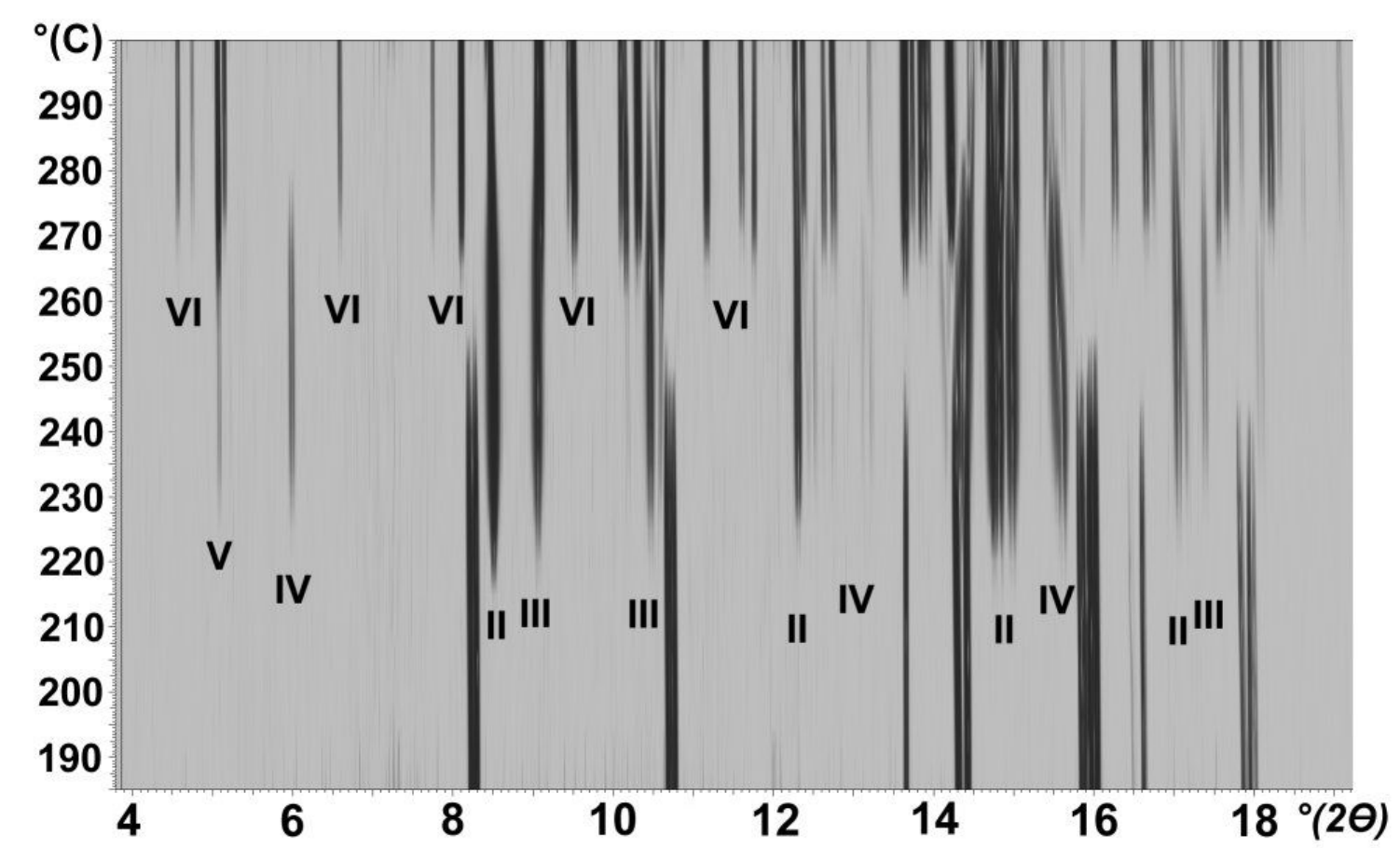

Figure 2. Contour plot from the synchrotron thermo-diffractometry on $\mathrm{K}_{2} \mathrm{ZrF}_{6}$ sample $\mathbf{1}$ in the range $185-300{ }^{\circ} \mathrm{C}$, on heating.

The $317^{\circ} \mathrm{C}$ DSC peak in Figure 1 is interpreted as the transition from form-VI to the tetragonal form-V which is the main phase up to $449{ }^{\circ} \mathrm{C}$ corresponding to the transition between the tetragonal form-V to a new phase VII accompanied by the reappearing of more of the cubic phaseIII. On cooling, the $411^{\circ} \mathrm{C}$ peak of the DSC corresponds to the reverse VII $\rightarrow \mathrm{V}$ transition, with a strong hysteresis. The tetragonal phase- $\mathrm{V}$ is then stable on cooling down to $139{ }^{\circ} \mathrm{C}$, where $\mathrm{K}_{2} \mathrm{ZrF}_{6}$ returns back to phase-I, monoclinic.

The new phases VI and VII were indexed by using the McMaille ${ }^{26}$ software and were found to be both orthorhombic. Phase IV could never be indexed. It is to be noted that its diffraction peaks are quite broader than for phases II (showing the narrowest peaks) and III. Hypotheses that the 
phase IV peaks could be sattellites of either a commensurate or an incommensurate supercell of either phases II or III found no success, so it cannot be excluded that what we call form-IV is in fact a mixture of 2 phases. Then the ab initio structure determination of phases V, VI and VII were undertaken with success by using the direct space Monte Carlo software $\operatorname{ESPOIR}^{27}$ (but the space group $P 4 / \mathrm{mmm}$ and the model proposed ${ }^{13}$ for the tetragonal $\mathrm{K}_{2} \mathrm{HfF}_{6}$ phase finally could not be applied to $\mathrm{K}_{2} \mathrm{ZrF}_{6}$ form-V). Rietveld ${ }^{28}$ refinement as well as Le Bail fits ${ }^{29}$ were realized by using the FULLPROF ${ }^{30}$ software. The cubic structure of $\mathrm{K}_{2} \mathrm{ZrF}_{6}$ form-III was better Rietveld-refined at $495{ }^{\circ} \mathrm{C}$ when mixed with form-VII, using the $\mathrm{K}_{3} \mathrm{ZrF}_{7}$ cubic structure ${ }^{31}$ as a starting model. Attempts to refine the hexagonal structure of form-II using the various proposed models for $\mathrm{K}_{2} \mathrm{HfF}_{6}$ were never satisfying due to the presence of phases III, IV (the latter unindexed) and V. Crystallographic data for the $\mathrm{K}_{2} \mathrm{ZrF}_{6}$ forms I to VII are summarized in Table 1 .

All the solid-state DFT structures optimizations were done according the procedure described elsewhere ${ }^{32}$.

Table 1. Crystallographic data for the $\mathrm{K}_{2} \mathrm{ZrF}_{6}$ forms I to VII (IV excluded)

\begin{tabular}{|c|c|c|c|c|c|c|}
\hline & I & II & III & $\mathrm{V}$ & VI & VII \\
\hline crystal system & monoclinic & hexagonal & cubic & tetragonal & orthorhombic & orthorhombic \\
\hline space group & $\mathrm{C} 2 / \mathrm{c}$ & $?$ & Fm-3m & $\mathrm{P} 4 / \mathrm{nmm}$ & $\mathrm{Cmcm}$ & Pnma \\
\hline temperature $(\mathrm{C})$ & $22 *$ & 264 & 495 & $200 * *$ & $295 / 54$ & 495 \\
\hline$(\mathrm{K})$ & 295 & 537 & 768 & 473 & $568 / 327$ & 768 \\
\hline$a(\AA)$ & $6.56646(2)$ & $6.4473(1)$ & $9.15641(3)$ & $6.33605(2)$ & $6.40840(5) / 6.37122(8)$ & $10.30844(7)$ \\
\hline$b(\AA)$ & $11.44440(4)$ & & & & $20.7697(2) / 20.5603(3)$ & $6.02909(3)$ \\
\hline$c(\AA)$ & $6.94202(2)$ & $3.8606(1)$ & & $9.29458(5)$ & $19.9888(2) / 19.6642(3)$ & $23.8017(2)$ \\
\hline$\beta$ (deg) & $90.5668(3)$ & & & & & \\
\hline$V\left(\AA^{3}\right)$ & $521.661(3)$ & $138.975(2)$ & $767.675(5)$ & $373.136(3)$ & $2660.52(4) / 2575.90(6)$ & $1479.29(2)$ \\
\hline$Z$ & 4 & 1 & 4 & 2 & 16 & 8 \\
\hline$V / Z$ & 130.41 & 138.97 & 191.92 & 186.57 & $166.28 / 160.99$ & 184.91 \\
\hline Wavelength $(\AA)$ & 0.82563 & 0.82695 & 0.82695 & 0.82695 & 0.82711 & 0.82695 \\
\hline $2 \theta$ range (deg) & $7-100$ & & $3-49$ & $4-59$ & $3-50$ / 3-60 & $3-49$ \\
\hline refined coordinates & 13 & & 3 & 6 & 32 & 32 \\
\hline soft restraints & none & & none & none & none & $18\left(\mathrm{ZrF}_{6}\right)$ \\
\hline$R_{P}$ & 3.82 & & 5.72 & 7.73 & $3.04 / 3.10$ & 5.72 \\
\hline$R_{W P}$ & 4.94 & & 9.69 & 10.5 & $4.65 / 4.45$ & 9.69 \\
\hline$R_{B}$ & 1.99 & & 4.14 & 5.10 & $7.63 / 6.03$ & 13.4 \\
\hline$R_{F}$ & 0.96 & & 5.67 & 7.97 & $7.85 / 5.25$ & 22.3 \\
\hline other phases & $\begin{array}{c}\mathrm{ZrO}_{2} \\
\mathrm{~K}_{3} \mathrm{ZrF}_{5} \mathrm{O} ?\end{array}$ & III, IV, V & VII, $\mathrm{ZrO}_{2}$ & III, $\mathrm{ZrO}_{2}$ & $\mathrm{IV}, \mathrm{V} / \mathrm{V}$ & III, $\mathrm{ZrO}_{2}$ \\
\hline
\end{tabular}




\author{
*after cooling from $470{ }^{\circ} \mathrm{C}$ \\ $* *$ on cooling direction from $500{ }^{\circ} \mathrm{C}$
}

\title{
RESULTS AND DISCUSSION
}

$\mathbf{K}_{2} \mathbf{Z r F}_{\mathbf{6}}$ form-I. In the whole range between the room temperature and the DSC peak at $240{ }^{\circ} \mathrm{C}$, form-I (previously noted $\alpha-\mathrm{K}_{2} \mathrm{ZrF}_{6}$ ) is found to be monoclinic ${ }^{4,5}$, however, peak shapes are so distorted and even split (in two or three components) that the Rietveld refinements are always quite bad. There was some controversy in the past about the symmetry: monoclinic or orthorhombic, monoclinic at room temperature and then possibly orthorhombic at higher temperature. For sample 1, the $0 \mathrm{k} 0$ reflections are split clearly in two main peaks (Figure 3), suggesting the existence of at least two microphases presenting different cell parameters. The splitting is visible at all temperatures. Comparison of samples $\mathbf{1}$ and $\mathbf{2}$ at $200{ }^{\circ} \mathrm{C}$ show that sample $\mathbf{2}$ looks much better than sample 1 but presents itself a small 0k0 splitting (see the 060 below) and is not free of peak shape problems (see the 133 or 422 in Figure 3). The Rietveld refinement for sample 2 at $200{ }^{\circ} \mathrm{C}$ led to $R_{P}=13.0 \%$ and $R_{B}=11.5 \%$, and it was not better than $R_{P}=35.1 \%$ and $R_{B}=24.3 \%$ for sample 1. Our explanation about these differences is that sample $\mathbf{1}$ was too highly crushed and that sample 2 was not enough crushed (the bad fit for sample 2 is not only due to broad peaks like the 422 or 133 , but also to some abnormally intense peaks typical of the presence of single crystals in the powder). Similar problems on sample grain size response was observed also on DTA/DSC experiments ${ }^{9}$. 


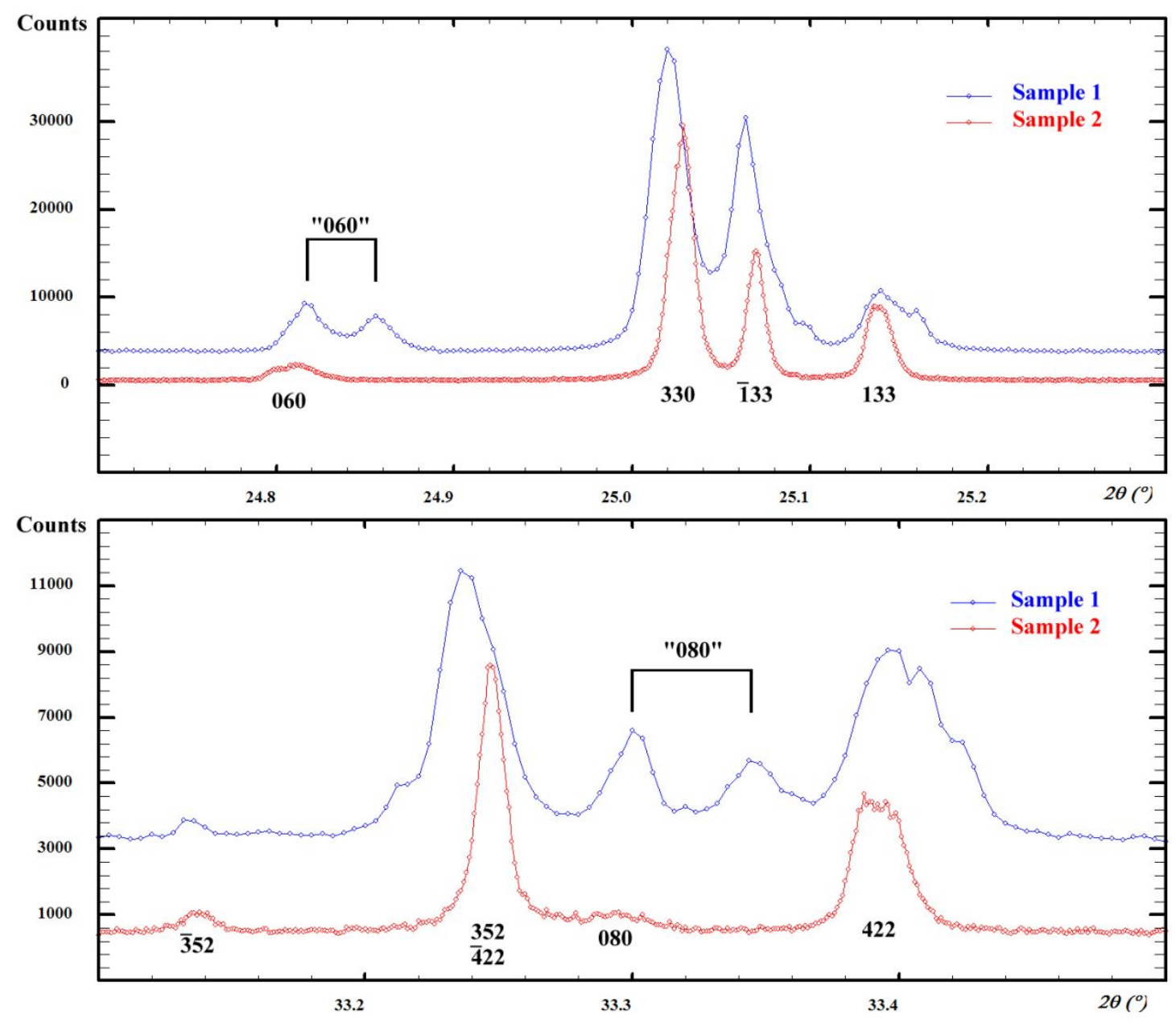

Figure 3. Parts of the synchrotron diffraction patterns of the two starting $\mathrm{K}_{2} \mathrm{ZrF}_{6}$ samples at $200{ }^{\circ} \mathrm{C}$ illustrating their differences and suggesting the coexistence of micro-phases with slightly different cell parameters.

Then, sample 2 was placed $12 \mathrm{~h}$ at $470{ }^{\circ} \mathrm{C}$, then cooled freely in order to see if some high temperature phase could be quenched. The result was the form-I presenting broader peaks than for unheated sample $\mathbf{1}$ and $\mathbf{2}$, but which produced an excellent fit (Figure 4) by the Rietveld method in spite of some anisotropic broadening which was treated by separating the much narrower h00 and hh0 from the others. This sample contains monoclinic $\mathrm{P} 2{ }_{1} / \mathrm{c} \mathrm{ZrO}_{2}$ as impurity, and also a third phase never encountered before, having peaks at positions very close to those of the cubic formIII, but convincingly indexed in a rhomboedral cell with parameters $\mathrm{a}=6.34818(5), \mathrm{c}=$ 15.65071(13) $\AA$, in too small proportion for an accurate structure refinement $\left(R_{B} \sim 10 \%\right.$ was obtained with the $\mathrm{R} \overline{3} \mathrm{~m}$ space group suggesting the $\mathrm{K}_{3} \mathrm{ZrF}_{5} \mathrm{O}$ formula, to be confirmed), so it was treated by a Le Bail fit, whereas $\mathrm{m}-\mathrm{ZrO}_{2}$ was treated by using the atomic coordinates from the literature, fixed. 


\begin{tabular}{|l|l|l|l|l|l|}
\hline & & & $0.04741(1)$ & & $0.01031(4)$ \\
\hline F1 & 8f & $0.28774(12)$ & $-0.01238(7)$ & $0.22121(13)$ & $1.56(2)$ \\
& & $0.2889(4)$ & $-0.014(3)$ & $0.220(1)$ & 0.91 \\
& & $0.2895(1)$ & $-0.0140(1)$ & $0.2191(2)$ & $0.0239(2)$ \\
\hline F2 & $8 \mathrm{f}$ & $0.19031(14)$ & $0.19056(7)$ & $0.27435(15)$ & $2.17(2)$ \\
& & $0.1900(5)$ & $0.1918(3)$ & $0.274(1)$ & 0.71 \\
& & $0.1899(1)$ & $0.1922(1)$ & $0.2746(1)$ & $0.0193(2)$ \\
\hline F3 & $8 \mathrm{f}$ & $-0.03405(15)$ & $0.09824(6)$ & $0.54599(11)$ & $1.58(2)$ \\
& & $-0.0362(5)$ & $0.0985(3)$ & $0.539(1)$ & 0.96 \\
& & $-0.0336(1)$ & $0.0986(1)$ & $0.5450(1)$ & $0.0193(2)$ \\
\hline
\end{tabular}

Table 3. Selected bond distances (angstroms) in $\mathrm{K}_{2} \mathrm{ZrF}_{6}$ form-I from synchrotron X-ray diffraction refinement

\begin{tabular}{|l|l|l|l|l|l|}
\hline bond & length & bond & length & bond & length \\
\hline Zr-F1 $\times 2$ & $2.0201(9)$ & K-F2 & $2.6897(11)$ & K-F2 & $2.8048(11)$ \\
\hline Zr-F2 $\times 2$ & $2.0691(10)$ & K-F1 & $2.7236(10)$ & K-F3 & $2.8256(8)$ \\
\hline Zr-F3 x 2 & $2.1503(8)$ & K-F2 & $2.7240(11)$ & K-F1 & $2.8274(10)$ \\
\hline Zr-F3 22 & $2.1946(8)$ & K-F2 & $2.7418(12)$ & K-F3 & $3.0206(11)$ \\
\hline average & 2.1085 & K-F1 & $2.7879(10)$ & K-F1 & $3.1272(10)$ \\
\hline & & & & average & 2.8273 \\
\hline
\end{tabular}

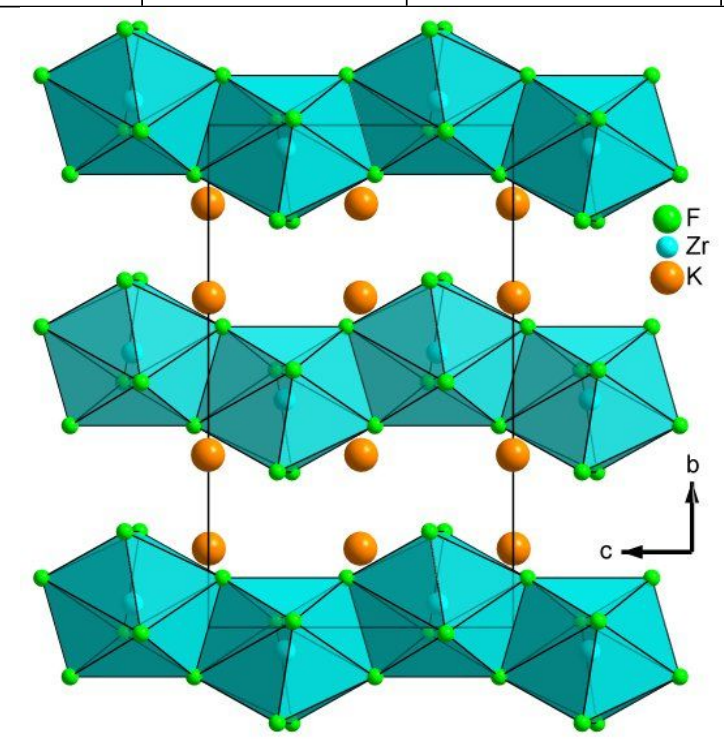

Figure 5. Projection of the unit cell of $\mathrm{K}_{2} \mathrm{ZrF}_{6}$ form-I along the $a$ axis showing the infinite chains of $\mathrm{ZrF}_{8}$ square antiprisms sharing edges.

$\mathrm{K}_{2} \mathrm{ZrF}_{\mathbf{6}}$ forms II, III and IV (=" $\boldsymbol{\beta}-\mathrm{K}_{2} \mathbf{Z r F}_{6}$ "). In spite of their strong differences, the two " $\mathrm{K}_{2} \mathrm{ZrF}_{6}$ form-I" samples produce very similar results after the first DSC peak at $240^{\circ} \mathrm{C}$. The 
comparison of a part of the two patterns at $265^{\circ} \mathrm{C}$ is made in Figure 6 . The diffraction peaks are narrower for sample $\mathbf{2}$ but this is due more probably to a better instrumental resolution.

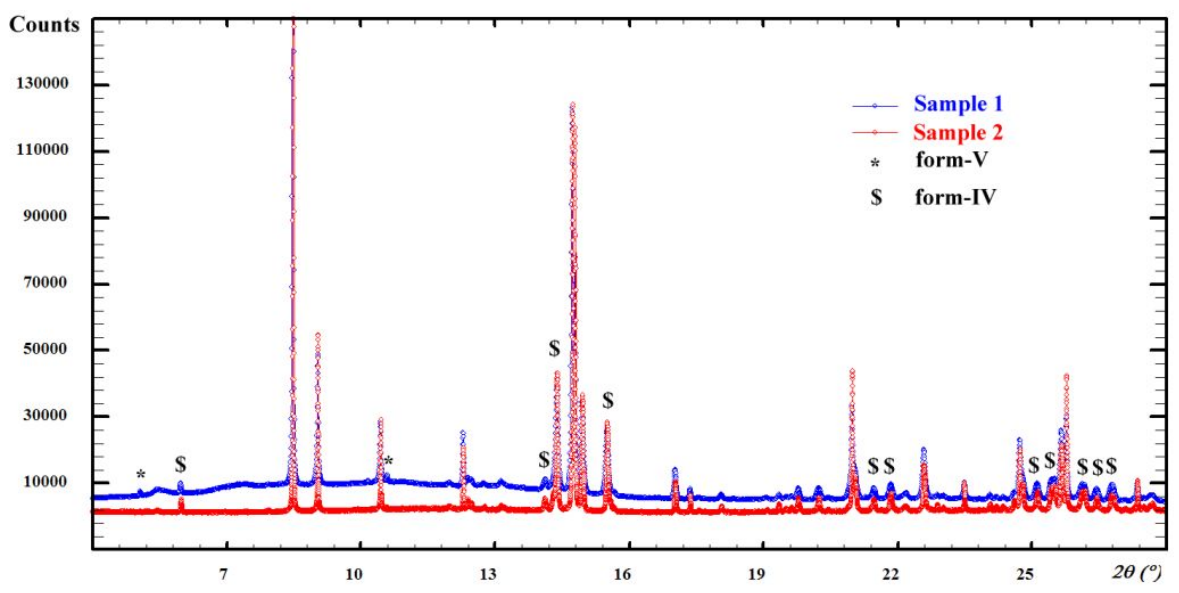

Figure 6. Comparison of the two samples synchrotron patterns at $265^{\circ} \mathrm{C}$. The tetragonal form- $\mathrm{V}$ is more present in the case of sample $\mathbf{1}$. Some of the main peaks corresponding to form-IV (unindexed) are indicated.

Once a convincing interpretation by pattern matching followed by peak indexing was established (see supplementary material) showing the simultaneous presence of up to four phases at this temperature $\left(265^{\circ} \mathrm{C}\right)$, a Le Bail fit was realized, including forms II and III, using excluded zones to discard forms IV (unindexed) and V, leading to the result shown in Figure 7. It can be noted that no peak splitting is observed, and that the peaks of the cubic phase (form-III) are narrower than those of the hexagonal form-II.

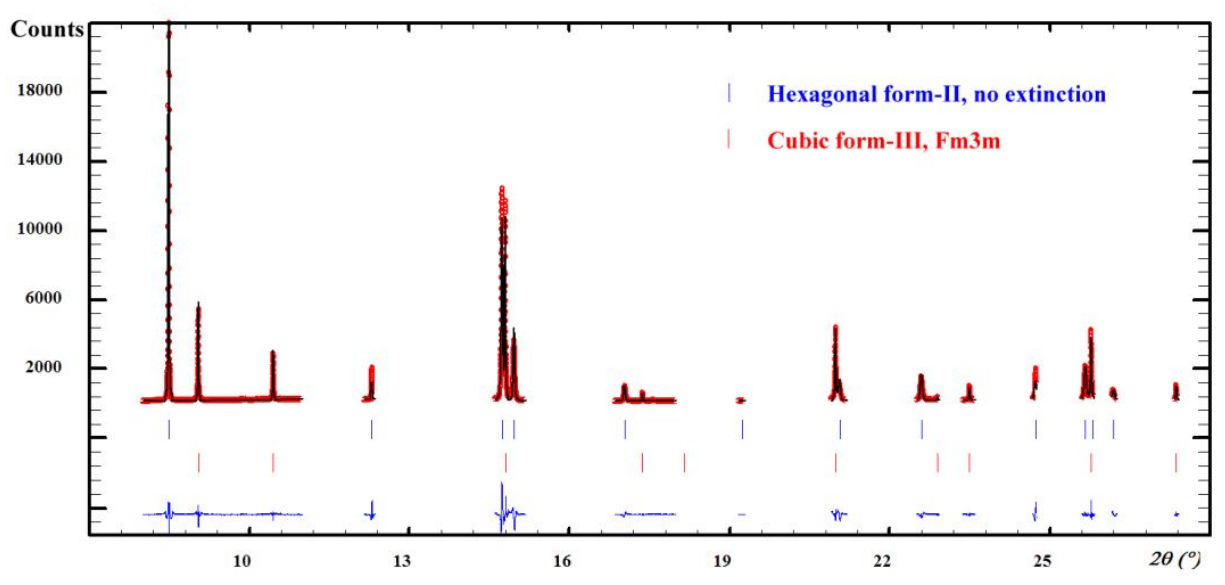

Figure 7. Le Bail fit on selected zones of the sample 2 synchrotron pattern at $265^{\circ} \mathrm{C}$ using only the dominant forms II and III. 
The absence of extinction leads to sixteen possible space groups for the hexagonal (or trigonal) form-II. It was proposed ${ }^{13}$ for the equivalent $\mathrm{K}_{2} \mathrm{HfF}_{6}$ form $(a=6.40, c=3.81 \AA$, "sometimes additional lines occur" in the $170-220^{\circ} \mathrm{C}$ range), but not confirmed by any refinement, that it could be isostructural with the $\beta_{1}-\mathrm{K}_{2} \mathrm{MF}_{6}\left(\mathrm{M}=\mathrm{U}\right.$, Th) investigated by Zachariasen ${ }^{23}$, with the space group $\mathrm{P} \overline{6} 2 \mathrm{~m}$. $\mathrm{Zr}$ would have an unusual ninefold coordination according to that model. Unfortunately, no satisfying Rietveld fit could be obtained by following this approach. No more success was obtained by trying other models selected among the $\mathrm{A}_{2} \mathrm{BX}_{6}$ known structures with relatively similar cell parameters, including the $\mathrm{K}_{2} \mathrm{GeF}_{6}$ structure-type ${ }^{33}$.

The cubic form-III could be best refined $\left(R_{B}=4.14 \%\right)$ by applying the $\mathrm{K}_{3} \mathrm{ZrF}_{7}$ model ${ }^{31}$ to the $495{ }^{\circ} \mathrm{C}$ synchrotron pattern (refined together with form-VII). Crystallographic parameters are gathered in Table S1 and interatomic distances in Table S2. The same model used in the attempts to fit the $264{ }^{\circ} \mathrm{C}$ complex pattern could lead to a Rietveld Bragg reliability $R_{B} \sim 14 \%$ while nothing better than $R_{B} \sim 25 \%$ was attained for form-II. It is believed that form-II belongs to the $\beta_{1}-\mathrm{K}_{2} \mathrm{MF}_{6}$ $(\mathrm{M}=\mathrm{U}, \mathrm{Th})$ structure type but that disorder exists and could not be characterized due to the mixture of phases. Indeed, the $\mathrm{K}_{3} \mathrm{ZrF}_{7}$ compound presents a strong disorder of the $\mathrm{F}$ atom positions so that it is difficult to estimate if all the zirconium polyhedra are $\mathrm{ZrF}_{7}$ ones or if there is a distribution of three possibilities including also $\mathrm{ZrF}_{6}$ and $\mathrm{ZrF}_{8}$ ones. This is not the same for $\mathrm{K}_{2} \mathrm{ZrF}_{6}$ form-III since all polyhedra around the zirconium have to be octahedra. If only the F1 atoms are considered, they build perfect $\mathrm{ZrF}_{6}$ octahedra $(\mathrm{Zr}-\mathrm{F}=1.977 \AA)$, but there is a non-negligible proportion of $\mathrm{F}$ atoms at the F2 position corresponding to longer $\mathrm{Zr}-\mathrm{F}$ distances $(2.178 \AA$ ) compatible with larger coordination which could not be compensated by smaller ones in this case, since the average polyhedra is $\mathrm{ZrF}_{6}$ that time. It is more probable that all polyhedra are $\mathrm{ZrF}_{6}$ octahedra adopting five possible positions: that corresponding to F1 or one of the four possibilities suggested by F2. Moreover, there is a supplementary cause for a disorder of the $\mathrm{F}$ atoms in $\mathrm{K}_{2} \mathrm{ZrF}_{6}$ form-III which is the partial occupancy of the potassium sites (fully occupied in $\mathrm{K}_{3} \mathrm{ZrF}_{7}$ ). In order to answer to the question "has this phase really a $\mathrm{K}_{2} \mathrm{ZrF}_{6}$ formula or is it in fact $\mathrm{K}_{3} \mathrm{ZrF}_{7}$ ?" we fixed the stoichiometry to the latter and the Rietveld $R_{B}$ value increased from 4.14 to $9.87 \%$. 


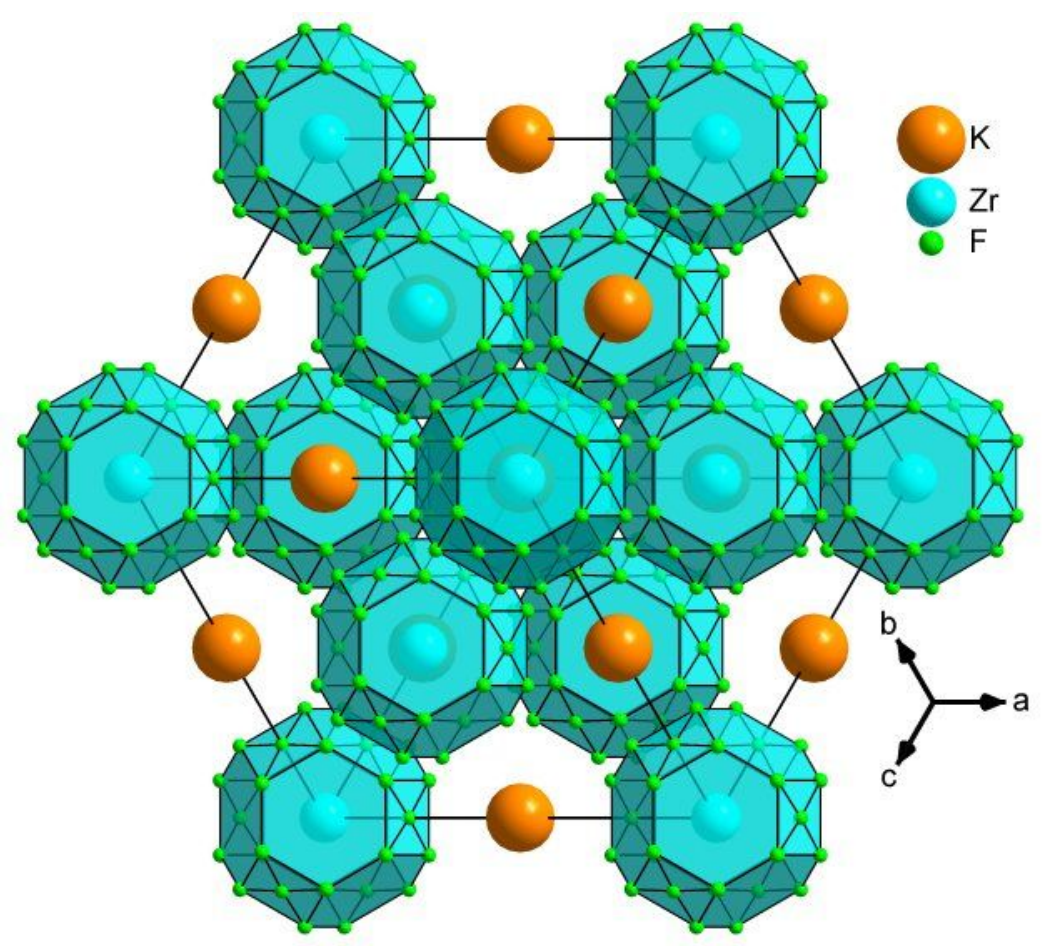

Figure 8. The structure of $\mathrm{K}_{2} \mathrm{ZrF}_{6}$ form-III projected along the [111] direction, with all possible positions for the $\mathrm{F}$ atoms represented, delimiting a kind of isolated sphere around of the $\mathrm{Zr}$ atoms due to the various orientations of the $\mathrm{ZrF}_{6}$ octahedra.

$\mathbf{K}_{2} \mathbf{Z r F}_{\mathbf{6}}$ form-V. This tetragonal form is present in large temperature ranges on heating (240$\left.449^{\circ} \mathrm{C}\right)$ and on cooling $\left(411-139^{\circ} \mathrm{C}\right)$, however, it is never a unique phase and the diffraction peaks are showing strange shapes/splitting, especially at the higher temperatures (Figure 9). It is to be noted that the $a$ cell parameter decreases when the temperature increases, whereas $c$ increases in a normal thermal expansion behaviour. 

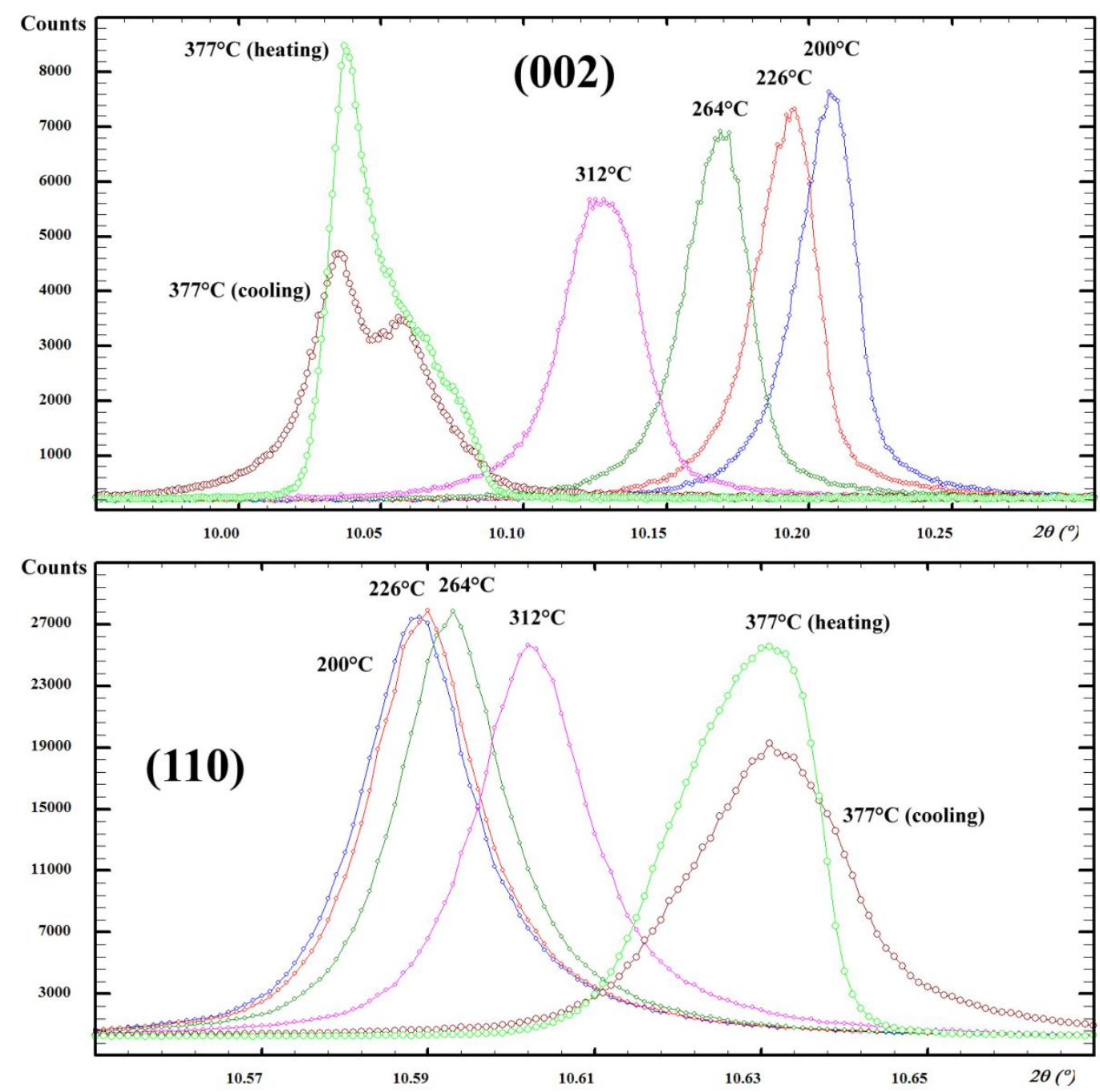

Figure 9. Splitting of the (002) reflection $\left(\mathrm{K}_{2} \mathrm{ZrF}_{6}\right.$ form-V) at the higher temperatures, strange peak shapes, $a$ cell parameter decreasing with the increasing temperature as seen from the (110) reflection positions. Where not specified, temperatures were on cooling from $495^{\circ} \mathrm{C}$.

The best pattern selected for the structure refinement is that of sample 2 at $200{ }^{\circ} \mathrm{C}$ on cooling. The space group $P 4 / \mathrm{mmm}$ proposed (no refinement) for the tetragonal form of $\mathrm{K}_{2} \mathrm{HfF}_{6}$ could not fit for $\mathrm{K}_{2} \mathrm{ZrF}_{6}$, the powder pattern showing clearly systematic extinctions leading to the P4/nmm space group. After structure solution, the refinement could be managed with an estimation of the anisotropic thermal parameters. The anisotropic peak broadening was undertaken by a simple approach, separating the narrower reflections (hh0) from the others. The crystallographic parameters and interatomic distances are in Tables S3 and S4, respectively. The Rietveld plot is in Figure 10. 
The crystal structure (Figure 11) of form-V is built up from $\mathrm{ZrF}_{6}$ octahedra, and $\mathrm{K}(1) \mathrm{F}_{6}$ octahedra (as in KF) alternating in corner-sharing chains with the $\mathrm{ZrF}_{6}$ ones (Figure 12). In these $\mathrm{K}(1) \mathrm{F}_{6}$ octahedra, the potassium atom is strongly off-centre. The second independent potassium atom $\mathrm{K}(2)$ is in a $8+4$ coordination very close to a cuboctahedron (the square faces are rectangularly distorted).

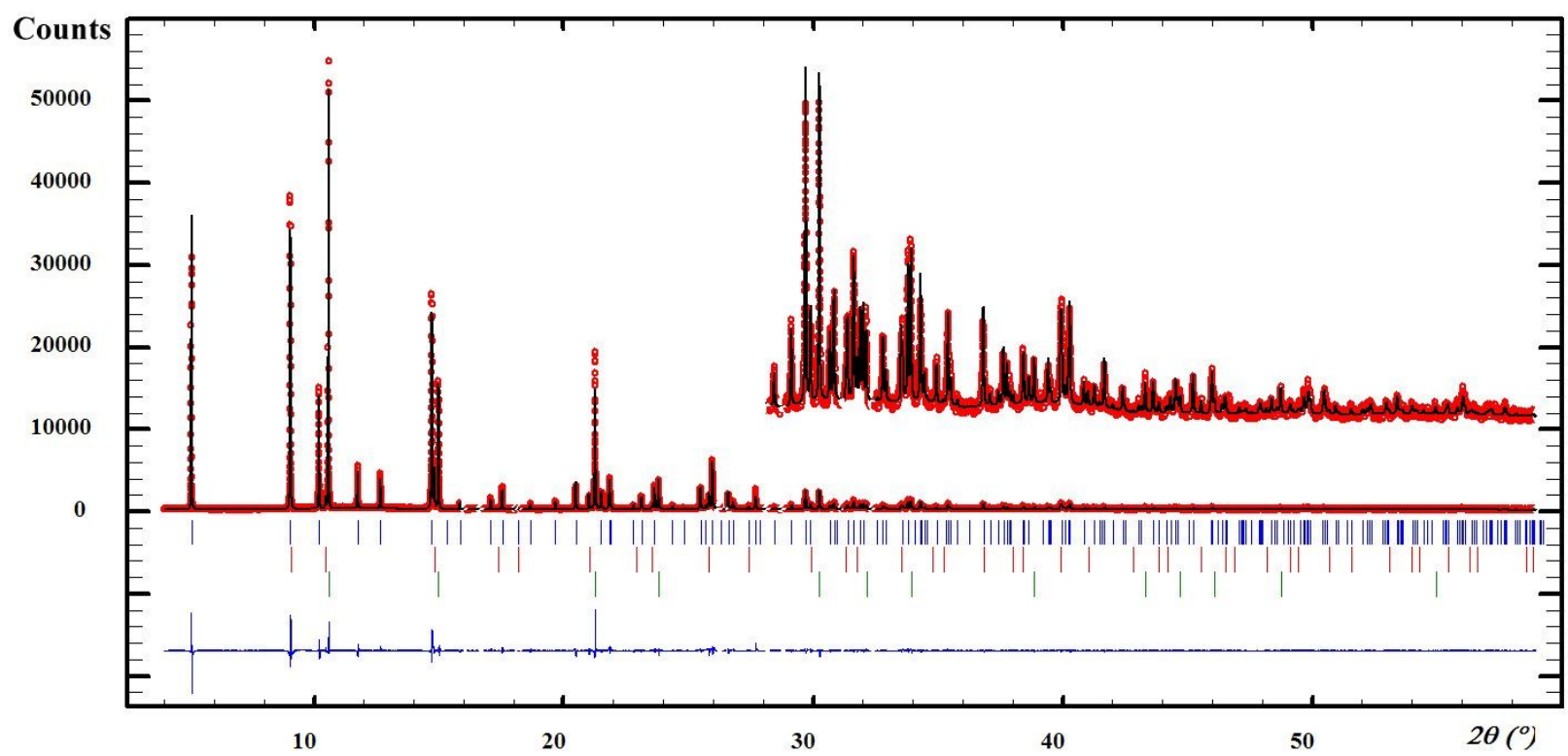

Figure 10. Refined diffraction pattern from synchrotron data for $\mathrm{K}_{2} \mathrm{ZrF}_{6}$ form- $\mathrm{V}$ at $200{ }^{\circ} \mathrm{C}$ on cooling. Red dots represent the observed data, the black line represents the calculated ones. Bragg ticks are the peak positions (3 sets from bottom to up: hk0 reflections of form- $\mathrm{V}$, cubic $\mathrm{K}_{2} \mathrm{ZrF}_{6}$ form-III, other peaks of form- $\mathrm{V}$ ) and the blue curve shows the difference between the observed and calculated patterns, $\lambda=0.82695 \AA$. Traces of $\mathrm{m}-\mathrm{ZrO}_{2}$ were managed by small excluded zones. 
Figure 11. Unit cell projection of the $\mathrm{K}_{2} \mathrm{ZrF}_{6}$ form-V (at $200^{\circ} \mathrm{C}$ on cooling) structure along the a axis. Ellipsoids are represented at $50 \%$ probability.

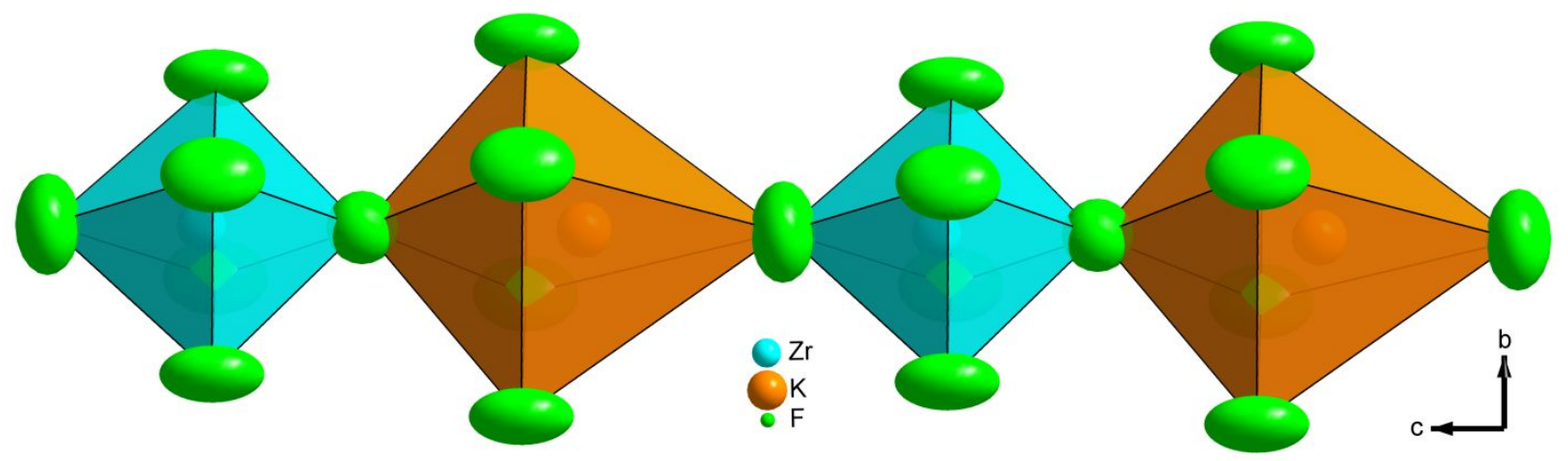

Figure 12. Alternating corner-sharing trans-chains of $\mathrm{ZrF}_{6}$ and $\mathrm{KF}_{6}$ octaedra along the $\mathrm{c}$ axis of the $\mathrm{K}_{2} \mathrm{ZrF}_{6}$ form-V structure. Ellipsoids are represented at 50\% probability.

$\mathbf{K}_{2} \mathbf{Z r F}_{\mathbf{6}}$ form-VI. This orthorhombic form (space group $\mathrm{Cmcm}$ ) has a small domain of existence in temperature $\left(288-317^{\circ} \mathrm{C}\right)$ and is mixed with form-V and form-III. The unindexed form-IV continues also to exist but its proportion decreases with the temperature increasing and the peaks become even broader than previously. A relatively fast cooling was made in situ during the synchrotron measurements (from sample 1) from 300 to $54{ }^{\circ} \mathrm{C}$, and the forms VI and V were also 
observed quenched at that temperature. The refined crystallographic parameters and interatomic distances are in Tables S5 and S6, respectively, and the Rietveld plots are in Figure $13\left(295^{\circ} \mathrm{C}\right)$ and $14\left(54^{\circ} \mathrm{C}\right)$.

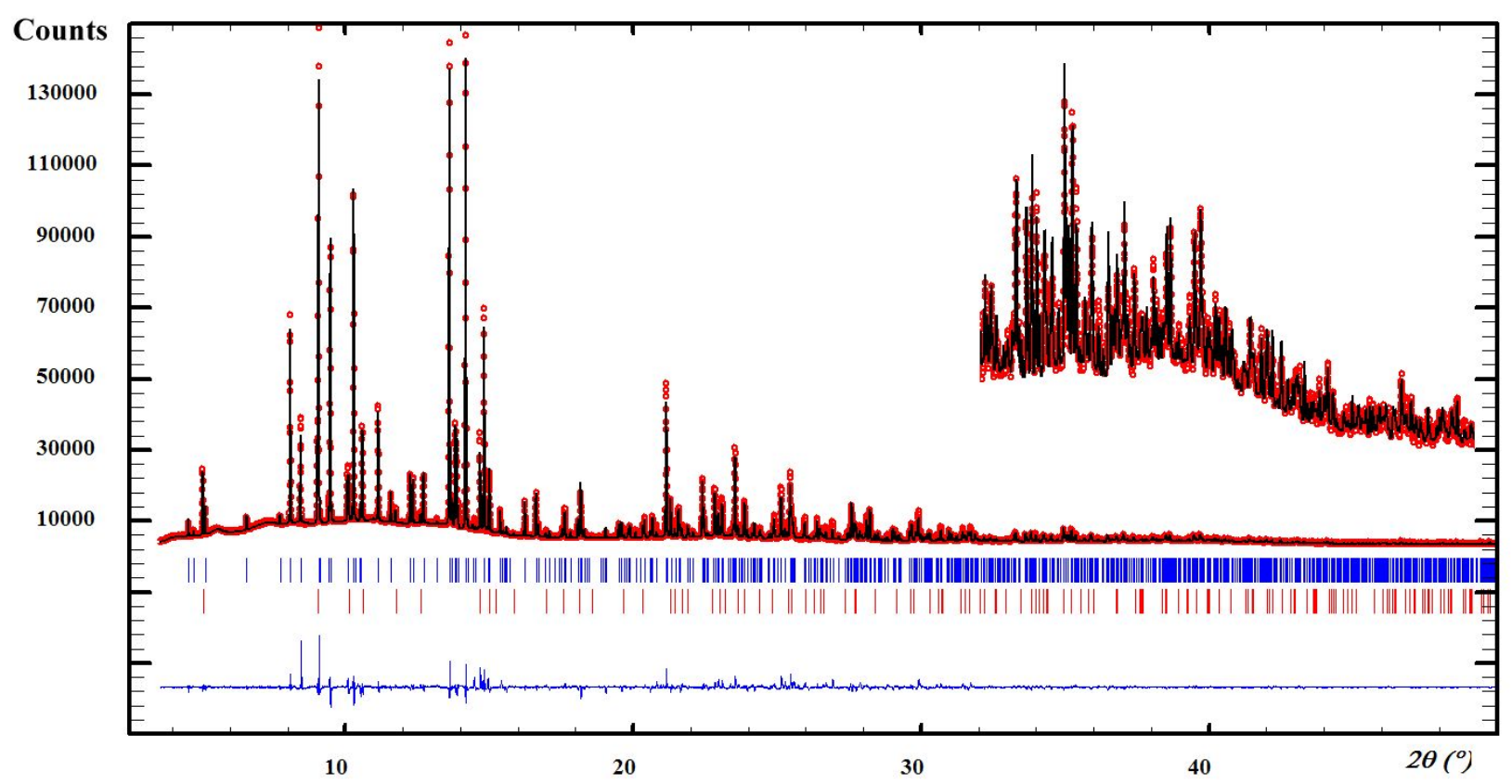

Figure 13. Refined diffraction pattern from synchrotron data for $\mathrm{K}_{2} \mathrm{ZrF}_{6}$ form-VI at $295{ }^{\circ} \mathrm{C}$. Red dots represent the observed data, the black line represents the calculated ones. Bragg ticks are the peak positions (up: form-VI, bottom: form $\mathrm{V}$ ) and the blue curve shows the difference between the observed and calculated patterns, $\lambda=0.82711 \AA$.

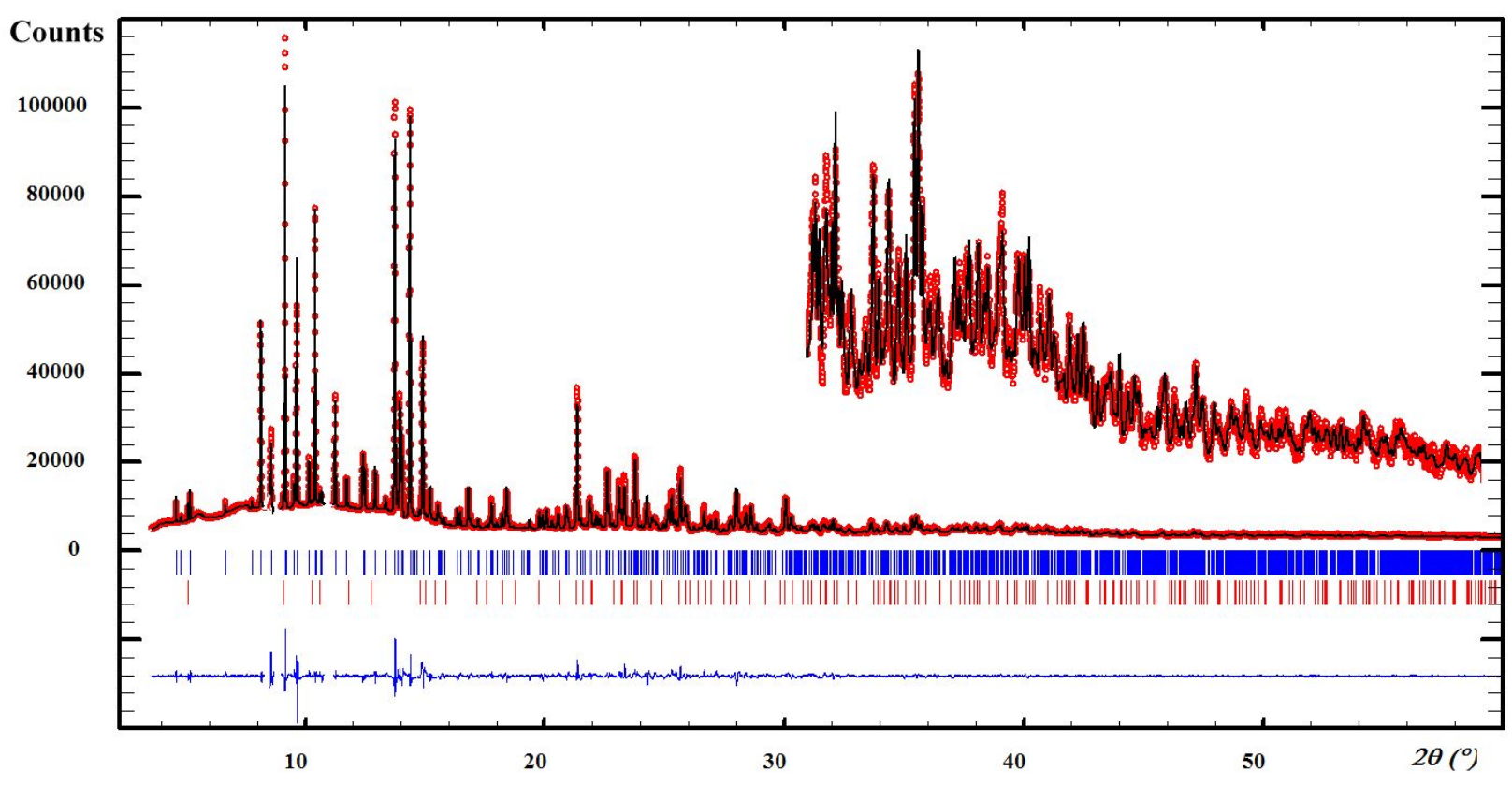


Figure 14. Refined diffraction pattern from synchrotron data for $\mathrm{K}_{2} \mathrm{ZrF}_{6}$ form-VI at $54{ }^{\circ} \mathrm{C}$ after natural cooling from $300{ }^{\circ} \mathrm{C}$. Red dots represent the observed data, the black line represents the calculated ones. Bragg ticks are the peak positions (up: form-VI, bottom : form V) and the blue curve shows the difference between the observed and calculated patterns, $\lambda=0.82711 \AA$.

As for form- $\mathrm{V}, \mathrm{K}_{2} \mathrm{ZrF}_{6}$ form-VI contains one isolated $\mathrm{Zr}(1) \mathrm{F}_{6}$ octahedra but there is also an uncommon dimeric entity formulated $\mathrm{Zr}_{2} \mathrm{~F}_{12}$ built from a $\mathrm{Zr}(2) \mathrm{F}_{7}$ monocapped trigonal prism sharing a corner with a $\mathrm{Zr}(3) \mathrm{F}_{6}$ octahedron (Figure 15). There are five different potassium atom sites, showing all a different polyhedral shape: $\mathrm{K}(1) \mathrm{F}_{8}$ is in a bicapped trigonal prism; $\mathrm{K}(2) \mathrm{F}_{11}$ is a tricapped cube; $\mathrm{K}(3) \mathrm{F}_{7}$ is a monocapped trigonal prism; $\mathrm{K}(4) \mathrm{F}_{6}$ is an octahedron; $\mathrm{K}(5) \mathrm{F}_{8}$ is a hexagonal-based bipyramid. There is a considerable decrease of the $b$ and $c$ axes lengths between 295 and $54{ }^{\circ} \mathrm{C}$. The atom which had a quite abnormally big thermal factor at $295{ }^{\circ} \mathrm{C}$ was $\mathrm{F}(9)$, but it is $\mathrm{F}(7)$ at $54^{\circ} \mathrm{C}$. Both fluorine atoms belong to the $\operatorname{Zr}(3)$ environment and show abnormally short $\mathrm{Zr}-\mathrm{F}$ distances which could be released according to some positional disorders presenting differences at the two temperatures.

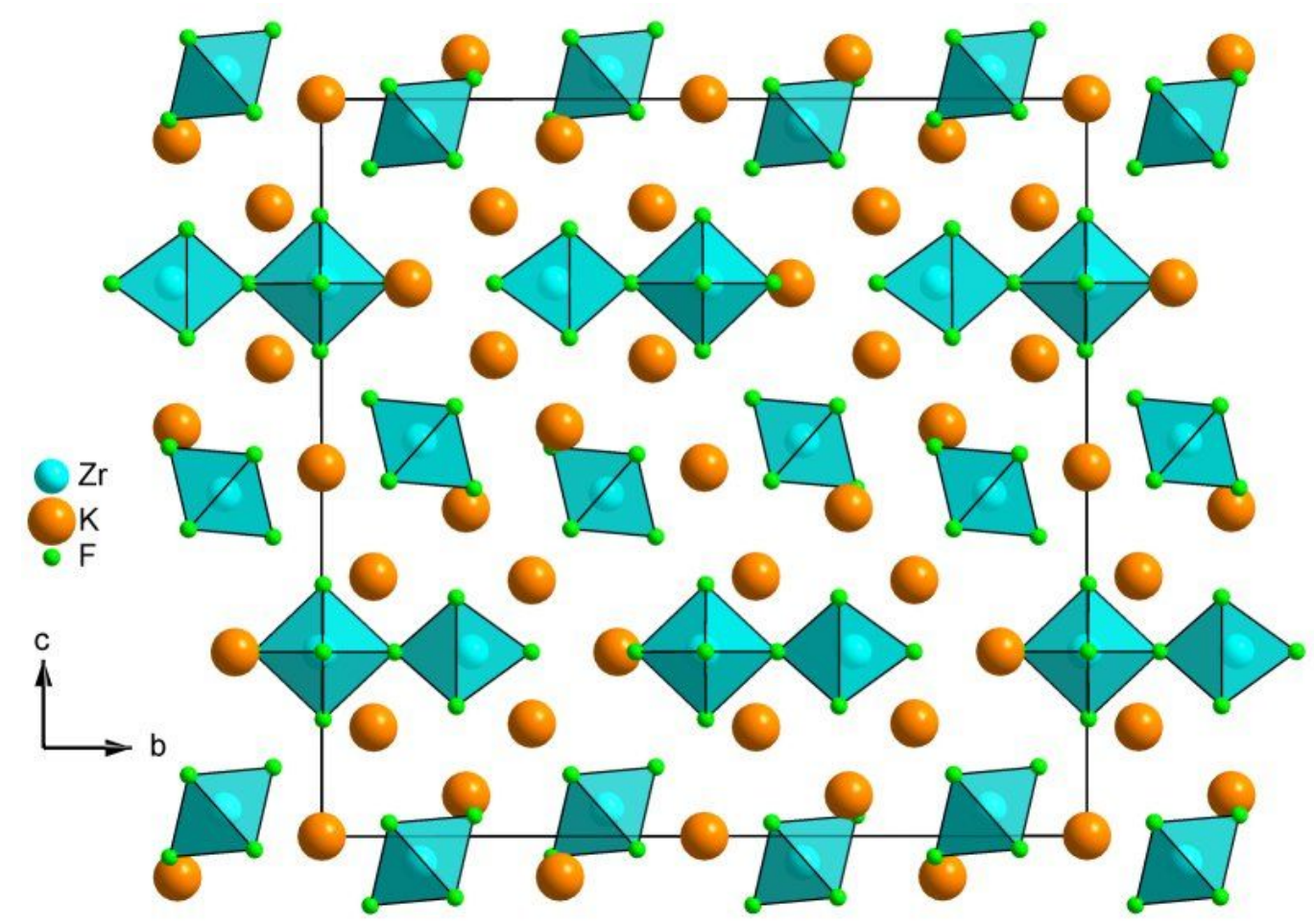

Figure 15. Unit cell projection of the $\mathrm{K}_{2} \mathrm{ZrF}_{6}$ form-VI (at $295^{\circ} \mathrm{C}$ ) structure along the short $a$ axis showing the isolated $\mathrm{ZrF}_{6}$ octahedra and the dimeric entities formulated $\mathrm{Zr}_{2} \mathrm{~F}_{12}$ built from a $\mathrm{ZrF}_{7}$ monocapped trigonal prism sharing a corner with a $\mathrm{ZrF}_{6}$ octahedron. 
$\mathbf{K}_{2} \mathbf{Z r F}_{6}$ form-VII. The pattern selected for structure solution and refinement is at $495^{\circ} \mathrm{C}$. Some $\mathrm{ZrO}_{2}$ is appearing due to the high reactivity of fluorides and the contact with the sapphire capillary. Two $\mathrm{ZrO}_{2}$ forms are present, the monoclinic and the tetragonal. The cubic form-III is present in large quantity so that its structure could be refined simultaneously as noted previously. The formVII refined crystallographic parameters and selected interatomic distances are in Tables S7 and S8, respectively, the Rietveld plot is in Figure 16.



Figure 16. Refined diffraction pattern from synchrotron data for $\mathrm{K}_{2} \mathrm{ZrF}_{6}$ form-VII at $495{ }^{\circ} \mathrm{C}$. Red dots represent the observed data, the black line represents the calculated ones. Bragg ticks are the peak positions (from up to down: orthorhombic form-VII, cubic form-III, tetragonal $\mathrm{ZrO}_{2}$, monoclinic $\mathrm{ZrO}_{2}$ ) and the blue curve shows the difference between the observed and calculated patterns, $\lambda=0.82695 \AA$. The splitting of some form-VII peaks is exemplified by the enlarged part showing the tripled 301 peak.

There are considerable differences between the DFT-optimized atomic coordinates and the Rietveld-refined ones and therefore on the interatomic distances (Tables S7 and S8). The indexing and the space group assignment were straightforward from the first 20 peaks at small diffraction angles, and the Le Bail fit allowed to extract intensities that led very directly to the full structural model by the direct space method. However, when the final Rietveld fit is examined in details, many peaks are badly fitted due to splitting (see especially the 301 peak split in three components in the Figure 16). There is no splitting at all for form-III peaks. Even if the $\mathrm{ZrF}_{6}$ octahedra were 
recognized at the solution stage, soft restraints had to be used on the $\mathrm{Zr}-\mathrm{F}$ distances during the refinement, in spite of which some distances are too short in Table S8. We have obviously to consider this structure as an imperfect approach, and even if the DFT optimization is capable to provide more realistic interatomic distances (to a point that we have chosen this time to show the drawing of the optimized crystal structure), using the fixed DFT coordinates does not improve the Rietveld fit, indeed, it is worst. Anyway, this phenomenon of peak splitting was also seen for form$\mathrm{V}$ especially at the vicinity of the reversible V↔VII transition, and also for some of the form-I various preparations. From the comparison of the crystal structures of forms VII and V (Figure 17), the V↔VII transition is more probably topotactic, given the cell parameters obvious relations $a_{\mathrm{VII}} \sim c_{\mathrm{V}}, b_{\mathrm{VII}} \sim b_{\mathrm{V}}, c_{\mathrm{VII}} \sim 4 a_{\mathrm{V}}$ and the observation that relatively small translations and rotations of the $\mathrm{ZrF}_{6}$ octahedra and translations of the $\mathrm{K}$ atoms allow to reproduce one crystal structure from the other. 


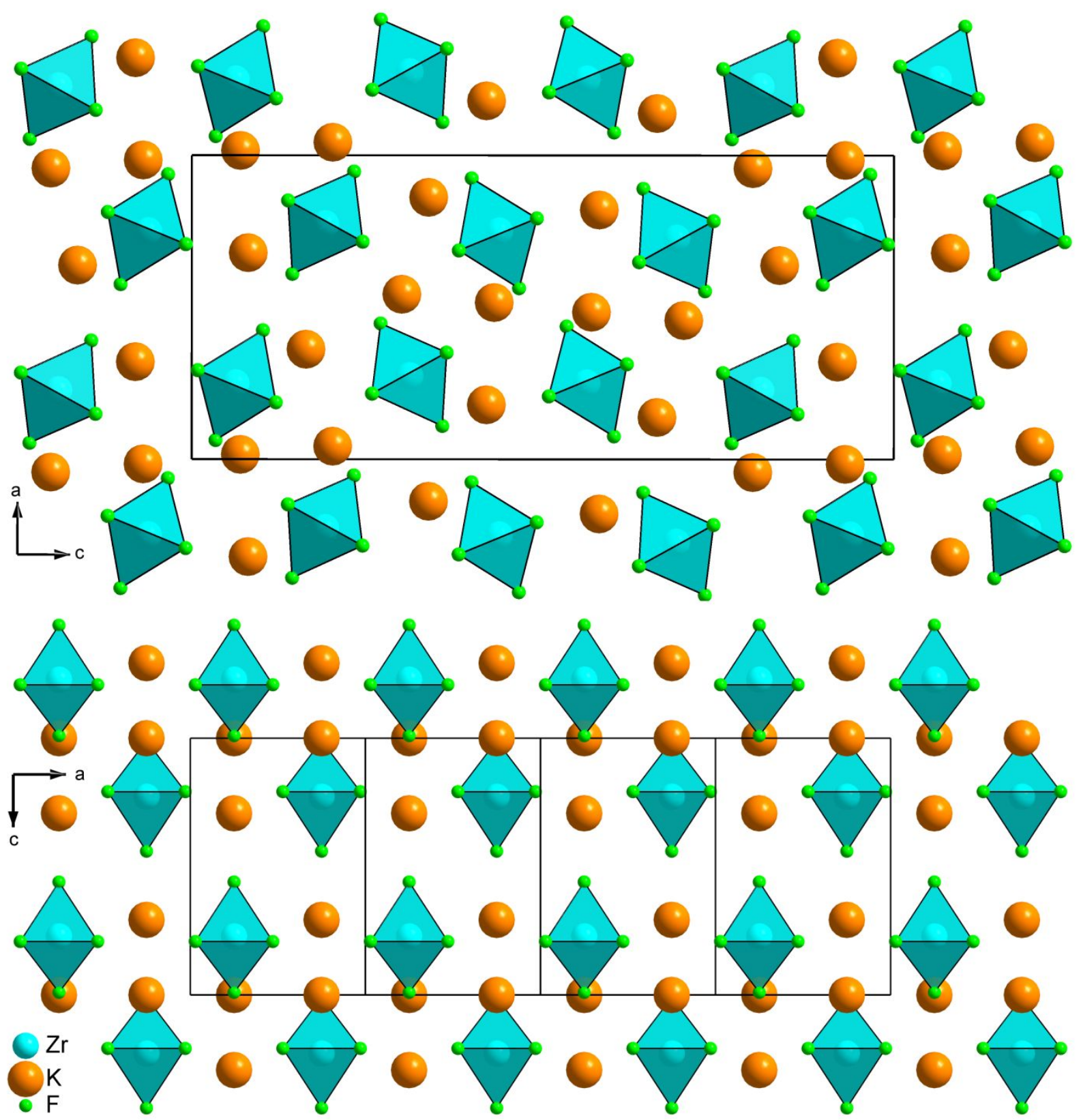

Figure 17. $\mathrm{K}_{2} \mathrm{ZrF}_{6}$ form-VII (up) DFT-optimized model compared to form-V (down) extended on four times the $a_{\mathrm{V}}$ cell parameter. The comparison shows the rotations and translations of $\mathrm{ZrF}_{6}$ octahedra as well as the translations of the $\mathrm{K}$ atoms occurring during the topotactic transition.

However, such a non-reconstructive transition suggests that a strong disorder may affect both phases since either $4 a_{\mathrm{V}}$ or $4 b_{\mathrm{V}}$ can become $c_{\mathrm{VII}}$, this could explain the quasi impossibility to fit the form-V powder patterns at high temperature, so that what we call "micro-phases" could correspond to different local arrangements at the interface of domains having the main structure. 
It is hard to give the polyhedra shapes around of the potassium atoms, if the limit in the K-F maximum distance is fixed at $3.5 \AA$, the polyhedra shapes may be slightly different in the DFToptimized and Rietveld-refined models.

Based on the XRD results the scheme a scheme of phase transformations of $\mathrm{K}_{2} \mathrm{ZrF}_{6}$ is suggested on Figure 18. In order to support the suggested models high temperature ${ }^{19} \mathrm{~F}$ MAS NMR spectroscopy was applied. As was mentioned in our previous work 9 , spectrum at $250{ }^{\circ} \mathrm{C}$ contains two resonances at $-16.3 \mathrm{ppm}$ and at $-33.7 \mathrm{ppm}$ with ratio $3: 1$, respectively. It should be noted that the signals have very different values of the chemical shift anisotropy, 28 and $10 \mathrm{ppm}$, respectively. An increase of the temperature from $250{ }^{\circ} \mathrm{C}$ to $290{ }^{\circ} \mathrm{C}$ leads to a decrease of the line width (full width at half-maximum, FWHM) for low field peak from 740 to $460 \mathrm{~Hz}$ and increase for high field signal from $440 \mathrm{~Hz}$ to $640 \mathrm{~Hz}$. In addition, a small shift of around $1 \mathrm{ppm}$ in low field was measured. At $310{ }^{\circ} \mathrm{C}$ two new peaks appear at -15.9 and $-19.1 \mathrm{ppm}$. In the range of the temperature $310-340$ ${ }^{\circ} \mathrm{C}$ we observe 4 signals. We note that at $340{ }^{\circ} \mathrm{C}$ two initially observed peaks almost disappeared. At $360^{\circ} \mathrm{C}$ the integral intensity of the resonance at $-15.5 \mathrm{ppm}$ reaches maximum and then it starts to decreases at $380{ }^{\circ} \mathrm{C}$ until the signal disappears completely at $410{ }^{\circ} \mathrm{C}$. At $410^{\circ} \mathrm{C}$ only one peak was observed. NMR data are summarized in Table 3.

Usually, at room temperature (or at lower temperatures) the high-resolution solid state NMR spectrum should contain the number of lines corresponding to the number of crystallographically non-equivalent atoms depending on the local chemical environment, in other words different nucleus in a molecule resonates at different frequencies. On other hand, the NMR spectra acquired in molten state consist in a single Lorentzian line, characteristic of a rapid exchange at the timescale of NMR between the different atomic configurations around the observed nucleus ${ }^{34}$. In some cases the measured chemical shift might thus be the average of the individual chemical shifts of the different species even at room temperature or temperatures below melting as was discussed many times for $\mathrm{K}_{2} \mathrm{TaF}_{7}{ }^{35}$ and refs. therein. Some other examples of the dynamics of fluorine atoms can be $\mathrm{Ba}_{5} \mathrm{AlF}_{13}{ }^{36}, \mathrm{Rb}_{3} \mathrm{TaOF}_{6}{ }^{37}$, or $\left(\mathrm{NH}_{4}\right)_{2} \mathrm{ZrF}_{6}{ }^{38}$.

In the present case, we observed a number of fluorine resonances much smaller than the number of non-equivalent fluorines. We explain this discrepancy by the dynamic behavior of fluorine atoms, which consists of a fast hoping of the fluorine on each position around one polyhedron. We think that in the measured spectra of $\mathrm{K}_{2} \mathrm{ZrF}_{6}$ we observe a dynamic behavior of fluorine atoms, each signal corresponds to a different polyhedron and the chemical shift is the barycenter of the 
individual resonances. Similar behavior was observed also in the case of $\mathrm{K}_{18} \mathrm{Ta}_{5} \mathrm{Zr}_{5} \mathrm{~F}_{63}$ compound 39.

In the range $250{ }^{\circ} \mathrm{C}$ to $290{ }^{\circ} \mathrm{C}$ we detected two signals for $\mathrm{K}_{2} \mathrm{ZrF}_{6}$. The value of the chemical shift at $-33.7 \mathrm{ppm}$ is slightly different from others, and it is very close to the signal of $\mathrm{K}_{3} \mathrm{ZrF}_{7}(-34 /-37$ ppm at $\mathrm{RT}{ }^{9,12}$ ), and we assigned this signal to the phase-III related to $\mathrm{K}_{3} \mathrm{ZrF}_{7}$. The second signal can be assigned to $\beta-\mathrm{K}_{2} \mathrm{ZrF}_{6}$. At $410{ }^{\circ} \mathrm{C}$ NMR spectrum is characterized by one line at $-18.2 \mathrm{ppm}$ and it can be attributed to the phase-VII with $\mathrm{ZrF}_{6}$ environments (Figure 19). The phase-VI consists of two different polyhedrons: $\mathrm{ZrF}_{6}$ and $\mathrm{Zr}_{2} \mathrm{~F}_{12}$. The signal at $-15.4 \mathrm{ppm}$ was assigned to dimeric fragment $\mathrm{Zr}_{2} \mathrm{~F}_{12}$ and signal around $-18.4 \mathrm{ppm}$ to the island like $\mathrm{ZrF}_{6}$ fragment. The phase transition between $390{ }^{\circ} \mathrm{C}$ and $410{ }^{\circ} \mathrm{C}$ is accompanied not by the appearance of a new signal, but by the disappearance of the signal at -15.3 ppm corresponding to the dimer $Z_{2} \mathrm{~F}_{12}$ and preserving the signal at $-18.3 \mathrm{ppm}$. Based on this observations it could be estimated that $\beta$-phase that was for the first time mentioned by ${ }^{3}$ and lastly discussed by ${ }^{9}$ probably consist of structural motives based on bridging of zirconium atoms by fluorine atoms; Zr-F-Zr.

The spectral changes were not reversible upon cooling to RT. A cooling up to $170{ }^{\circ} \mathrm{C}$ does not lead to changes in the spectrum, only one line was observed, which just shifted from $-18.2 \mathrm{ppm}$ $\left(410^{\circ} \mathrm{C}\right)$ to $-20 \mathrm{ppm}\left(170^{\circ} \mathrm{C}\right)$. Then two new small peaks were observed. In order to reach the maximum resolution, a very fast spinning rate of $50 \mathrm{kHz}$ was used after cooling the sample. As in case the heating-cooling cycle RT- $250{ }^{\circ} \mathrm{C}$-RT ${ }^{9}$, in addition to the expected signals for the $\alpha$-phase $(\mathrm{I}=97.3 \%)$, two small signals at $-34.6 \mathrm{ppm}(\mathrm{I}=1.6 \%)$ and $-36.7 \mathrm{ppm}(\mathrm{I}=0.1 \%)$ were detected. This spectral evolution during the cooling process is in a good agreement with the obtained XRD data. 
Table 3. ${ }^{19} \mathrm{~F}$ NMR data obtained from the simulation of the ${ }^{19} \mathrm{~F}$ NMR spectra at $17.6 \mathrm{~T}$ and MAS $7 \mathrm{kHz}$ during the heating of the sample from RT up to $410{ }^{\circ} \mathrm{C}$

\begin{tabular}{|c|c|c|c|c|c|c|c|c|c|}
\hline \multirow[b]{2}{*}{$\mathrm{T},{ }^{\circ} \mathrm{C}$} & \multicolumn{2}{|c|}{$\mathrm{Zr}_{2} \mathrm{~F}_{12}$} & \multicolumn{2}{|c|}{$\mathrm{ZrF}_{6}$} & \multicolumn{2}{|c|}{$\beta-\mathrm{K}_{2} \mathrm{ZrF}_{6}$} & \multicolumn{2}{|c|}{ phase-III $\left(\mathrm{K}_{3} \mathrm{ZrF}_{7}\right)$} & \\
\hline & $\begin{array}{c}\delta_{\text {iso }}, \mathrm{ppm} \\
( \pm 0.1 \mathrm{ppm})\end{array}$ & $\begin{array}{l}\text { Integral, } \\
\%( \pm 1 \%)\end{array}$ & $\begin{array}{c}\delta_{\text {iso }}, \mathrm{ppm} \\
( \pm 0.1 \mathrm{ppm})\end{array}$ & $\begin{array}{l}\text { Integral, } \\
\%( \pm 1 \%)\end{array}$ & $\begin{array}{c}\delta_{\text {iso }}, \mathrm{ppm} \\
( \pm 0.1 \mathrm{ppm})\end{array}$ & $\begin{array}{l}\text { Integral, } \\
\%( \pm 1 \%)\end{array}$ & $\begin{array}{c}\delta_{\text {iso }}, \mathrm{ppm} \\
( \pm 0.1 \mathrm{ppm})\end{array}$ & $\begin{array}{l}\text { Integral, } \\
\%( \pm 1 \%)\end{array}$ & \\
\hline 410 & - & - & -18.2 & 100 & - & - & - & - & phase-VII \\
\hline 390 & -15.3 & 16.8 & -18.3 & 83.2 & - & - & - & - & \multirow{4}{*}{ phase-VI } \\
\hline 380 & -15.4 & 39 & -18.4 & 61 & - & - & - & - & \\
\hline 380 & -15.4 & 52.9 & -18.4 & 47.1 & - & - & - & - & \\
\hline 360 & -15.5 & 75 & -18.8 & 25 & - & - & - & - & \\
\hline 340 & -15.6 & 75 & -18.8 & 23 & -13.3 & 1 & -32.9 & 1 & phase-VI; \\
\hline 320 & -15.8 & 70 & -19 & 24 & -14 & 4 & -33.1 & 2 & $\beta$-phase; \\
\hline 310 & -15.9 & 7 & -19.1 & 30 & -14.7 & 51 & -33.2 & 12 & phase-III \\
\hline 290 & - & $\begin{array}{l}- \\
-\end{array}$ & - & - & -15.1 & 80 & -33.2 & 20 & $\begin{array}{c}\text { phase-II + } \\
\text { Phase-IV = } \\
\beta \text {-phase; }\end{array}$ \\
\hline 250 & - & & - & & -16.3 & 77 & -33.7 & 23 & phase-III \\
\hline
\end{tabular}




\section{$240-264^{\circ} \mathrm{C}$}

Phase I up to $240^{\circ} \mathrm{C}$
RT, monoclinic
$a=6.5704(6) \AA$
$b=11.4502(10) \AA$
$c=6.9465(6) \AA$
$\beta=90.528(2)$
$C 12 / \mathrm{c} 1$ - 250371-ICSD

$139^{\circ} \mathrm{C}$

Phase III- $\mathrm{ZrF}_{6}$

temperature
Phase VI- $\mathrm{ZrF}_{6}, \mathrm{Zr}_{2} \mathrm{~F}_{12}$

orthorhombic (space group $\mathrm{Cmcm}, a=$

6.40840 (5) $\AA, b=20.7697(2) \AA, c=$

$19.9888(2) \AA$, at $295^{\circ} \mathrm{C}, Z=16$ )

$a=6.4473(1) \AA, c=3.8606(1) \AA$ at $264^{\circ} \mathrm{C}, Z=1$

cubic (space group $F m \overline{3} m, a=9.0804$ (1) $\AA$ at

$\left.264^{\circ} \mathrm{C}, Z=4\right)$, related to $\mathrm{K}_{3} \mathrm{ZrF}_{7}$

Phase IV (unindexed) vanishing with

Phase V (weak impurity at $240^{\circ} \mathrm{C}$ )

cubic (space group $F m \overline{3} m, a=9.1564$ (3) $\AA$ at $\left.495^{\circ} \mathrm{C}, Z=4\right)$, related to $\mathrm{K}_{3} \mathrm{ZrF}_{7}$

Figure 18. Scheme of phase transformations of $\mathrm{K}_{2} \mathrm{ZrF}_{6}$. 


\section{CONCLUSIONS}

From this study, not everything is explained yet (forms II and IV, more details on hypothetical micro-phases) but a considerable step is made in the knowledge of the $\mathrm{K}_{2} \mathrm{ZrF}_{6}$ complex polymorphism that reveals to be seriously different from the old expectations. An incredible diversity of polyhedral shapes is adopted by the zirconium and the potassium atoms, with coordinations from 6 to 7 and 6 to 12 , respectively. The " $\beta-\mathrm{K}_{2} \mathrm{ZrF}_{6}$ " phase characterized previously by hyperfine quadrupolar interaction of ${ }^{181} \mathrm{Ta}$ at $\mathrm{Zr}$ sites ${ }^{40}$, or by RAMAN ${ }^{41}$ and NMR ${ }^{7}$ before any crystallography study, is a mixture of up to four phases, indeed, two of which being still not completely understood (forms-II and IV). Three new crystal structures types were established $a b$ initio from powder diffraction data for forms-V, VI and VII. Rietveld refinements were concluding for the ubiquitous cubic form-III related to $\mathrm{K}_{3} \mathrm{ZrF}_{7}$ suggesting a possible conduction by $\mathrm{K}^{+}$ions as a consequence of $2 / 3$ sites occupied. Strange enough is the fact that the forms VI and VII at high temperature present both a lower symmetry (orthorhombic with $Z=16$ and 8 , respectively) than the tetragonal form-V $(Z=2)$ existing also at much lower temperatures. A scheme of phase transformations of $\mathrm{K}_{2} \mathrm{ZrF}_{6}$ was suggested. It could be noted that the phase transformation of $\mathrm{K}_{2} \mathrm{ZrF}_{6}$ (here all $\mathrm{Zr}$ atoms are eight coordinated at $\mathrm{RT}$ forming $\mathrm{ZrF}_{8}$ ) is related with the breaking of infinite 
chains of bridged zirconia atoms through $\mathrm{F}$ atoms followed by the formation of phase with dimeric fragments finished with island like fragment of $\mathrm{ZrF}_{6}$.

A re-examination of the polymorphism of $\mathrm{K}_{2} \mathrm{HfF}_{6}$ looks desirable, given the high degree of isomorphism of $\mathrm{Zr}$ - and $\mathrm{Hf}$-based fluorides. The fact is that no $\mathrm{K}_{2} \mathrm{HfF}_{6}$ powder patterns corresponding to our $\mathrm{K}_{2} \mathrm{ZrF}_{6}$ complex forms VI and VII (nor IV) was observed, though the forms I, II, III and V were listed ${ }^{13}$ together with some others which we could not disclose. In case of future use of the $\mathrm{K}_{2} \mathrm{ZrF}_{6}$ formulation for the "Generation IV" Molten Salts Nuclear Reactors, these results will have to be taken into consideration, especially the strong variation of the volume occupied by the molecular unit in the various solid states when cooling from the molten state. The nice dream of a phase transition from a crystal structure to another, both perfectly ordered, is not fulfilled in the $\mathrm{K}_{2} \mathrm{ZrF}_{6}$ case, for reasons remaining to be explained.

\section{ASSOCIATED CONTENT}

Supplementary material contain crystallographic parameters and selected bond distances or $\mathrm{K}_{2} \mathrm{ZrF}_{6}$ forms III, V, VI and VII phases tables of indexed powder patterns of phases I-VII, full dataset for $\mathrm{K}_{2} \mathrm{ZrF}_{6}$ at $265^{\circ} \mathrm{C}$ and a CIF file for every synchrotron refinement including the Fullprof .pcr and .dat files for Rietveld or Le Bail fits. This material is available free of charge via the internet at http://pubs.acs.org.

\section{CORRESPONDING AUTHOR}

*Institute of Inorganic Chemistry, Department of molten systems, Dubravska cesta 9, Bratislava; 845 36, Slovakia. E-mail: miroslav.boca@savba.sk.

\section{ACKNOWLEDGMENTS}

This work was supported by the Slovak Research and Development Agency under the contract No. APVV-15-0479. This work was financially supported by the Scientific Grant Agency of the Ministry of Education of the Slovak Republic and the Slovak Academy of Sciences, grant no. Vega 2/0024/20. Financial support from TGIR-RMN-THC Fr3050 CNRS for conducting the research is gratefully acknowledged.

\section{References}


(1) DoE, U. S., A Technology Roadmap for Generation IV Nuclear Energy Systems. https://www.gen-4.org/gif/jcms/c_40481/technology-roadmap. 2002.

(2) Forsberg, C. W., Hydrogen, nuclear energy, and the advanced high-temperature reactor. Int. J. Hydrogen Energy 2003, 28, 1073-1081.

(3) Novoselova, A. V.; Korenev, Y. M.; Simanov, Y. P., The KF-ZrF4 system. Dokl. Akad. Nauk SSSR 1961, 139, 892-894.

(4) Hoppe, R.; Mehlhorn, B., Die Kristallstruktur von K2ZrF6. Z. Anorg. Allg. Chem. 1976, 425, 200-208.

(5) Gerasimenko, A. V.; Tkachenko, I. A.; Kavun, V. Y.; Didenko, N. A.; Sergienko, V. I., Synthesis and complex investigation of potassium ammonium hexafluorozirconates: I. Synthesis and X-ray diffraction study of $\mathrm{K} 2-\mathrm{x}(\mathrm{NH} 4) \mathrm{xZrF} 6(0<\mathrm{x}<2)$ crystals. Russ. J. Inorg. Chem. 2006, $51,9-22$.

(6) Bode, H.; Teufer, G., Über Strukturen von Hexafluorozirkonaten und Hexafluorohafnaten. Z. Anorg. Allg. Chem. 1956, 283, 18-25.

(7) Kavun, V. Y.; Sergienko, V. I.; Uvarov, N. F., Ion Mobility and Electrophysical Properties of Potassium Hexafluorozirconate K2ZrF6. J. Struct. Chem. 2003, 44, 796-802.

(8) Hruška, B.; Netriová, Z.; Vasková, Z.; Boča, M.; Chromčíková, M.; Liška, M., Hightemperature Raman study of K2ZrF6 phase transitions. J. Alloys Compd. 2019, 791, 45-50.

(9) Boča, M.; Netriová, Z.; Rakhmatullin, A.; Vasková, Z.; Hadzimová, E.; Smrčok, L.; Hanzel, O.; Kubíková, B., The differing responses of various techniques in measuring the phase transformations of K2ZrF6. J. Mol. Liq. 2019, 110969.

(10) Kubikova, B.; Mackova, I.; Boca, M., Phase analysis and volume properties of the (LiFNaF-KF)(eut)-K2ZrF6 system. Monatsh. Chem. 2013, 144, 295-300.

(11) Boča, M.; Barborík, P.; Mičušík, M.; Omastová, M., X-ray photoelectron spectroscopy as detection tool for coordinated or uncoordinated fluorine atoms demonstrated on fluoride systems NaF, K2TaF7, K3TaF8, K2ZrF6, Na7Zr6F31 and K3ZrF7. Solid State Sci. 2012, 14, 828-832.

(12) Rakhmatullin, A.; Boča, M.; Mlynáriková, J.; Hadzimová, E.; Vasková, Z.; Polovov, I. B.; Mičušík, M., Solid state NMR and XPS of ternary fluorido-zirconates of various coordination modes. J. Fluorine Chem. 2018, 208, 24-35.

(13) Saalfeld, H.; Guse, W., The polymorphism of dipotassium hexafluorohafnate. Neues Jahrb. Mineral., Abh. 1983, 146, 29-40.

(14) Gerasimenko, A. V.; Didenko, N. A.; Kavun, V. Y., Dipotassium hexafluoridozirconate(IV) hydrogen fluoride, K2ZrF6·HF. Acta Crystallogr., Sect. E: Struct. Rep. Online 2007, 63, i171.

(15) Hampson, G. C.; Pauling, L., The Structure of Ammonium Heptafluozirconate and Potassium Heptafluozirconate and the Configuration of the Heptafluozirconate Group. J. Am. Chem. Soc. 1938, 60, 2702-2707.

(16) Massiot, D.; Fayon, F.; Capron, M.; King, I.; Le Calvé, S.; Alonso, B.; Durand, J.-O.; Bujoli, B.; Gan, Z.; Hoatson, G., Modelling one- and two-dimensional solid-state NMR spectra. Magn. Reson. Chem. 2002, 40, 70-76.

(17) Thompson, S. P.; Parker, J. E.; Potter, J.; Hill, T. P.; Birt, A.; Cobb, T. M.; Yuan, F.; Tang, C. C., Beamline I11 at Diamond: a new instrument for high resolution powder diffraction. Rev. Sci. Instrum. 2009, 80, 075107.

(18) Thompson, S. P.; Parker, J. E.; Marchal, J.; Potter, J.; Birt, A.; Yuan, F.; Fearn, R. D.; Lennie, A. R.; Street, S. R.; Tang, C. C., Fast X-ray powder diffraction on I11 at Diamond. J. Synchrotron Radiat. 2011, 18, 637-648. 
(19) Parker, J. E.; Thompson, S. P.; Cobb, T. M.; Yuan, F.; Potter, J.; Lennie, A. R.; Alexander, S.; Tighe, C. J.; Darr, J. A.; Cockcroft, J. C.; Tang, C. C., High-throughput powder diffraction on beamline I11 at Diamond. J. Appl. Crystallogr. 2011, 44, 102-110.

(20) Sabelli, C., Structure refinement of elpasolite from Cetine Mine, Tuscany, Italy. Neues Jahrb. Mineral., Monatsh. 1987, 481-487.

(21) Bode, H.; Voss, E., Strukturen der Hexafluorometallate(III). Z. Anorg. Allg. Chem. 1957, 290, 1-16.

(22) Schefer, J.; Schwarzenbach, D.; Fischer, P.; Koetzle, T.; Larsen, F. K.; Haussuhl, S.; Rudlinger, M.; McIntyre, G.; Birkedal, H.; Burgi, H.-B., Neutron and X-ray Diffraction Study of the Thermal Motion in K2PtCl6 as a Function of Temperature. Acta Crystallogr., Sect. B: Struct. Sci. 1998, 54, 121-128.

(23) Zachariasen, W. H., Double Fluorides of Potassium or Sodium with Uranium, Thorium or Lanthanum. J. Am. Chem. Soc. 1948, 70, 2147-2151.

(24) Eva softwer-Bruker. http://www.crystallography.net/pcod/P2D2/EVA/index.html.

(25) PDF (2012). PDF4+ database, International Centre for Diffraction Data, Newtown Square, PA.

(26) Le Bail, A., Monte Carlo indexing with McMaille. Powder Diffr. 2004, 19, 249-254.

(27) Le Bail, A., ESPOIR: A Program for Solving Structures by Monte Carlo Analysis of Powder Diffraction Data. Mater. Sci. Forum 2001, 378-381, 65-70.

(28) Rietveld, H. M. J., A Profile Refinement Method for Nuclear and Magnetic Structure. $J$. Appl. Crystallogr. 1969, 2, 65-71.

(29) Le Bail, A., Whole powder pattern decomposition methods and applications: A retrospection. Powder Diffr. 2005, 20, 316-326.

(30) Rodríguez-Carvajal, J., Recent advances in magnetic structure determination by neutron powder diffraction. Physica B: Condensed Matter 1993, 192, 55-69.

(31) Single crystal data for K3ZrF7 unpublished

(32) Le Bail, A.; Smrcok, L., Face-sharing octahedra in Cs3Al2F9 and Cs2AlF5. Powder Diffr. 2015, 30, 130-138.

(33) Hoard, J. L.; Vincent, W. B., Structures of Complex Fluorides. Potassium Hexafluogermanate and Ammonium Hexafluogermanate. J. Am. Chem. Soc. 1939, 61, 2849-2852.

(34) Bessada, C.; Rollet, A.-L.; Rakhmatullin, A.; Nuta, I.; Florian, P.; Massiot, D., In situ NMR approach of the local structure of molten materials at high temperature. C. R. Chim. 2006, 9, 374380.

(35) Boca, M.; Rakhmatullin, A.; Mlynarikova, J.; Hadzimova, E.; Vaskova, Z.; Micusik, M., Differences in XPS and solid state NMR spectral data and thermo-chemical properties of isostructural compounds in the series KTaF6, K2TaF7 and K3TaF8 and KNbF6, K2NbF7 and K3NbF8. Dalton T 2015, 44, 17106-17117.

(36) Martineau, C.; Allix, M.; Suchomel, M. R.; Porcher, F.; Vivet, F.; Legein, C.; Body, M.; Massiot, D.; Taulelle, F.; Fayon, F., Structure determination of Ba5AlF13 by coupling electron, synchrotron and neutron powder diffraction, solid-state NMR and ab initio calculations. Dalton Trans. 2016, 45, 15565-15574.

(37) Laptash, N. M.; Udovenko, A. A.; Emelina, T. B., Dynamic orientation disorder in rubidium fluorotantalate. Synchronous Ta-O and Ta-F vibrations. Journal of Fluorine Chemistry 2011, 132, 1152-1158.

(38) Voit, E. I.; Voit, A. V.; Kavun, V. Y.; Sergienko, V. I., Quantum-chemical study of potassium and ammonium hexafluorozirconates. J. Struct. Chem. 2004, 45, 610-616. 
(39) Boča, M.; Molokeev, M.; Rakhmatullin, A.; Netriova, Z., The structure of the metastable K18Ta5Zr5F63 phase. New J. Chem. 2020, submitted.

(40) Martínez, J. A.; Rodríguez, A. M.; Caracoche, M. C.; Mercader, R. C.; López Garcia, A. R.; Rivas, P. C., Temperature dependence of the hyperfine quadrupolar interaction in K2ZrF6. Hyperfine Interact. 1983, 13, 307-313.

(41) Dracopoulos, V.; Vagelatos, J.; Papatheodorou, G. N., Raman spectroscopic studies of molten $\mathrm{ZrF} 4-\mathrm{KF}$ mixtures and of $\mathrm{A} 2 \mathrm{ZrF6}, \mathrm{A} 3 \mathrm{ZrF} 7$ (A = Li, K or Cs) compounds. Dalton Trans. 2001, 1117-1122. 


\title{
For Table of Contents Use Only
}

\author{
Polymorphism of $\mathrm{K}_{2} \mathrm{ZrF}_{6}$ \\ Lubomír Smrčo ${ }^{\dagger}$, Armel Le Bail, Miroslav Boca*, Aydar Rakhmatullin

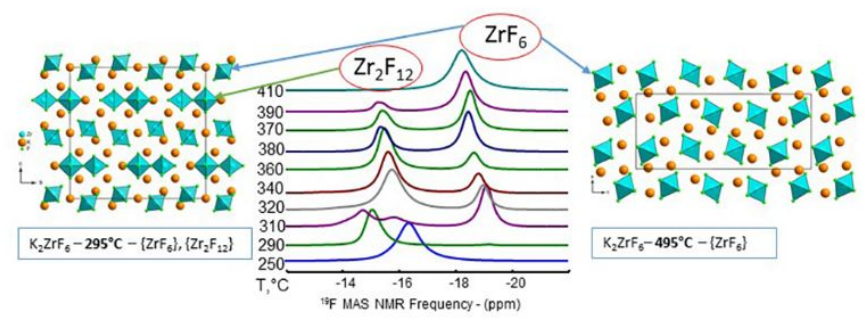

\section{SYNOPSIS}

Phase transformations of $\mathrm{K}_{2} \mathrm{ZrF}_{6}$ were analysed in situ using synchrotron powder diffraction and high temperature ${ }^{19}$ F MAS NMR. Exceptional multiple solid-solid transformation was described. 


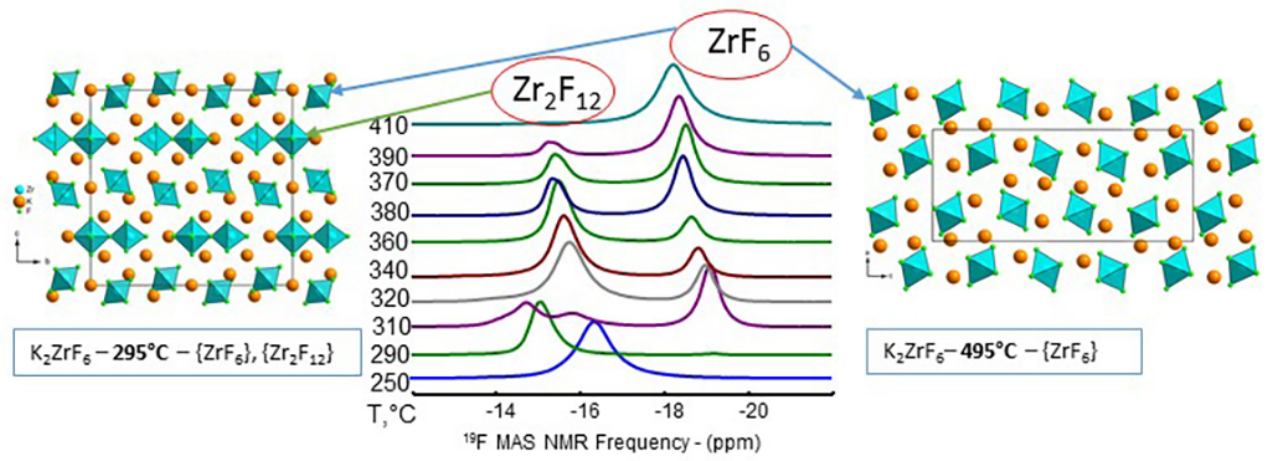

$88 \times 33 \mathrm{~mm}(300 \times 300$ DPI $)$ 